\title{
Mobility and Social Change: Understanding the European Neolithic Period after the Archaeogenetic Revolution
}

\author{
Martin Furholt ${ }^{1}$ \\ Published online: 4 January 2021 \\ (c) The Author(s) 2021
}

\begin{abstract}
This paper discusses and synthesizes the consequences of the archaeogenetic revolution to our understanding of mobility and social change during the Neolithic period in Europe (6500-2000 BC). In spite of major obstacles to a productive integration of archaeological and anthropological knowledge with ancient DNA data, larger changes in the European gene pool are detected and taken as indications for large-scale migrations during two major periods: the Early Neolithic expansion into Europe (6500-4000 BC) and the third millennium BC "steppe migration." Rather than massive migration events, I argue that both major genetic turnovers are better understood in terms of small-scale mobility and human movement in systems of population circulation, social fission and fusion of communities, and translocal interaction, which together add up to a large-scale signal. At the same time, I argue that both upticks in mobility are initiated by the two most consequential social transformations that took place in Eurasia, namely the emergence of farming, animal husbandry, and sedentary village life during the Neolithic revolution and the emergence of systems of centralized political organization during the process of urbanization and early state formation in southwest Asia.
\end{abstract}

Keywords Neolithic of Europe $\cdot$ aDNA studies $\cdot$ Mobility and migration · Social organization · Neolithic revolution · Urbanization

\section{Introduction}

In the last few years, technological and methodological advances in molecular biological studies have had a massive impact on our ways of thinking about European prehistory. Ancient DNA studies (aDNA) have produced so many new datasets, simulations, and models that the archaeological community has had

Martin Furholt

martin.furholt@iakh.uio.no

1 Department of Archaeology, Conservation and History, University of Oslo, P.O. Box 1019, Blindern, 0315 Oslo, Norway 
problems keeping up with it. In an influential contribution, Kristiansen (2014) enthusiastically welcomed this development as part of a new swing toward a more scientific, data-focused approach to prehistory. To him, this is part of "a larger shift from postmodernity to a revised modernity" (Kristiansen 2014, p. 23), though conceding that archaeologists still need to develop the proper theoretical tools to deal with these data.

Very prominently, the concept of migration, long deemed outdated, has reentered and even started to dominate the discourse around European prehistory. Leaving out the Paleolithic period here (e.g., López et al. 2016), aDNA studies have now pointed toward two main periods of severe changes in the gene pool that are interpreted as the result of significant population movements: the beginning of the Neolithic period, since $6500 \mathrm{BC}$ (Bramanti et al. 2009) and the onset of the European Bronze Age, in the third millennium BC (Allentoft et al. 2015; Haak et al. 2015).

However, we are still far away from understanding these newly discovered phenomena of human mobility in terms of prehistoric social change. When it comes to the "third-science revolution" that Kristiansen hails, we are actually much worse off than he acknowledges. Not only have we so far failed to develop a new theoretical basis to integrate the new wealth of aDNA data for the prehistory of humans, we have not even been able to integrate the current state of theoretical awareness into the archaeogenetic discourse (see Furholt 2018b; Hofmann 2015; Ion 2017; Johannsen et al. 2017; Müller 2013; Sørensen 2017; Vander Linden 2016). Instead, long outdated and dismissed concepts were reactivated to create simple, easily accessible models to make sense of the archaeogenetic data.

While there are nuances, the main problem with most variants of the archaeogenetic migration narrative (most explicitly in Brandt et al. 2013; Haak et al. 2015; Kristiansen et al. 2017) is that it relies on the flawed and outdated concept that archaeological classification units-usually referred to as "archaeological cultures"-would represent distinct and clearly delineated human groups of common genetic ancestry and social identity. This concept of the archaeological culture sprang out of 19th century romantic nationalism, the belief in culturally and biologically homogeneous territorial groups as the essential form of human organization (Trigger 2006). It was brought into the archaeological discourse in an intellectual climate of nationalist, chauvinist, and racist attitudes with an explicit nationalist and social Darwinist agenda by Kossinna $(1910,1911,1919)$ in an attempt to prove Germanic seniority and superiority over neighboring peoples. While there is no doubt about the importance of Kossinna for the development of early prehistoric archaeology in Europe, this should not be mistaken as a sign of scholarly quality. Indeed, his original work clearly demonstrates a striking simplicity of thinking and a sloppy methodology, which he compensates with drastic personal attacks on any critic of his work (e.g., Kossinna 1919). As a result, his concept is inherently flawed. It presupposes a strict congruence between material culture, ethnic identity, and biological descent (or in his words, race); archaeological cultures were defined as representing socially bounded, culturally uniform groups of people who occupied a clearly delineated, continuous territory. They were, literally, seen as the precursors of modern European nation-state peoples, projected into prehistory. 
Kossinna ignored the fact that such a situation of congruency of regional distribution patterns of specific archaeological object types-e.g., pottery, tools, jewelry, house forms, burial rituals-exists virtually nowhere in the European archaeological record. Instead, he worked around this inconvenience by defining archaeological cultures using only one single type of artifact, mostly pottery, after whose specific types many cultures are named (e.g., Linear Pottery culture, Corded Ware culture, Funnel Beaker culture). The step of further investigating whether or not the spatial distribution of specific types of associated stone tools, house forms, or burial rituals would actually match the regions defined via pottery style has, ever since the time of Kossinna, been largely skipped, probably because it almost never worked (e.g., Furholt 2008). These "cultures" were then treated as if they had a common agency, and change happened through contact between them, or their collective migration. Childe adopted this concept and popularized it in a wider international context (1929), dropping the idea of a racial connotation of archaeological cultures in the face of emerging fascism in Europe (1933). Since these early days, almost all theoretical assumptions underlying the concept of the archaeological culture have been convincingly deconstructed. Cultural boundaries are usually not at all fixed, stable, or relate to every aspect of social life, and they are not necessarily territorial (Barth 1969. Ethnic identities are situational and dynamic (Shennan 1989; Wotzka 1993). Material culture can convey socially relevant meaning, but it is not necessarily connected to ethnicity (Hodder 1982; Lüning 1972). In the archaeological record, configurations of regional coherence between different kinds of cultural expressions almost never exist, so Kossinna's "clearly bounded territories" are an illusion (Clarke 1968; Furholt 2008; Müller 2001; Roberts and Vander Linden 2011).

The critique that processual archaeologists launched against culture historical archaeology was effective enough to focus attention away from cultures as the acting units (Trigger 2006, p. 392). In addition, later, postprocessual archaeologists were not interested in cultures or ethnic identities in prehistory, as it had been sufficiently demonstrated that the former are modern illusions and the latter historical constructions, both subjective categorizations that are not well represented by mapping archaeological objects (e.g., Hodder 1982). However, it is mostly overlooked that processual and postprocessual archaeology were schools of thought that gained dominance in some archaeological communities, while in others, and indeed in most of Europe, they played only marginal roles (Biehl et al. 2002; Gramsch 2011; Härke 1995). Thus, while many English-speaking academic communities (the United Kingdom and Ireland, plus some Dutch and Scandinavian institutions) have largely abandoned the concept of archaeological cultures, the majority of European colleagues still refer to such units as their main tool for making sense of prehistory. Despite having been challenged, deconstructed, and rejected, the concept of the archaeological culture has shown a remarkable resilience among the vast majority of archaeologists in Europe. Many colleagues have continued using the terminology, claiming their heuristic value as a tool of classification, while renouncing any ethnic connotation or association with distinct social groups (e.g., Lüning 1972). This is, however, a problematic position, as the archaeological culture concept carries the heavy ideological baggage of presupposing cultural coherence, i.e., homogeneity within and boundedness toward the outside world. Using this concept to classify 
the archaeological material thus tends to create an illusion of such a coherence by brushing over, or at least downplaying, phenomena of intermixture and overlap of different kinds of artifacts and the underlying phenomena of cultural plurality, diversity, hybridity, and other expressions of social reality (e.g., Furholt 2019b; Wotzka 1993). Even worse, many other colleagues have continued to see archaeological cultures as representing distinct groups of people with a common identity (see Eggert 1978; Furholt 2009; Veit 1989; Wotzka 1993).

During the first boom of ancient DNA studies, in part surely due to strict word limits in the chosen publication venues, simplified narratives were produced that come very close to traditional Kossinna-like ways of thinking, as archaeological cultures were taken to represent biological populations (Furholt 2018b; Heyd 2017; Müller 2013). Doing so, the Neolithization of Europe is reduced to a migration of a biologically distinct group of southwest Asian origin. Even more pronounced, the third millennium genetic transformation is portrayed as a westward "massive migration" of "the Yamnaya," creating "the Corded Ware culture" and "the Beaker folk" in central and western Europe (see Barras 2019). This is no more than a caricature of real social processes, which are a complicated amalgam of long-term processes and intermediate and small-scale events and histories. If we want to discuss the spread of Neolithic ways of life into Europe, we deal with a period of 4000 years, and we have to account for processes that started around $6500 \mathrm{BC}$ in eastern Greece and northwestern Turkey and reached Norway and Finland around 2500 BC. During this time, the continent of Europe saw fundamental transformations from communities based on hunting, fishing, and gathering to settlements where animals and plants were domesticated.

Genetics now reveals that this was accompanied by a significant influx of new biological lineages with a strong connection to Anatolia. But saying that the Neolithization of Europe was caused by migration is a meaningless phrase at best. More likely it is misleading, as it evokes images of peoples' movements or intentional settler colonialism. It also suggests that Neolithization would be one distinct, clearly definable process, an unrealistic suggestion given the temporal dimensions and the variability in the archaeological record of which we are talking (e.g., Robb 2013). In parallel, the third millennium BC Yamnaya or "steppe migration" is a catchword for a more dynamic interregional interaction between eastern and central Europe, which seems to have started in the late fifth millennium BC, when "steppe elements" begin to appear in the archaeological record of southeastern Europe and the Carpathian Basin (see Heyd 2017), and continued until the third millennium, when burial rites and settlement patterns were fundamentally altered. Even here, however, there is considerable variability in the specific manifestations of these transformations in different regions, suggesting the effects of multiple different social processes (Furholt 2014; Kaiser 2019; Vander Linden 2006).

In this paper, I criticize the inherently monothetic view of migration in prehistoric Europe, the simplistic narrative of two distinct migration events of circumscribed groups of people. Instead, I provide alternative accounts that reflect a view of prehistoric social organization and mobility based on the anthropological and archaeological state of the art and more firmly build on our current knowledge of both the archaeological material and the new biomolecular data. While the social reality 
of migration processes is complex and diverse, I identify the prime movers behind the two main population turnovers in Europe. These consequential social transformations had their beginnings in southwest Asia: first, the development of farming, animal breeding, and the first concentrated permanent villages, established in the ninth-eighth millennia $\mathrm{BC}$, and, second, early urbanization and state formation and the connected ideological and social changes in the third millennium BC.

The paper is set up in two parts. First, the current state of debates surrounding Neolithic expansion into Europe is discussed, based on the archaeological and recent aDNA evidence. This is followed by a discussion of the archaeological and archaeogenetic evidence that relates to the third millennium BC steppe migration hypothesis. Here, special emphasis is placed on a critique of the most elaborate narrative laid out by Kristiansen et al. (2017) and the proposition of an alternative.

\section{The Spread of Neolithic Ways of Life into Europe}

\section{The Archaeological Record of Neolithic Expansions into Europe}

What is usually defined as "Neolithic" in Europe-a lifestyle based on the exploitation of domesticated plants and animals, combined with higher degrees of sedentism-was established in southwest Asia, in long-lasting, complex processes culminating between roughly 10,000 and $8000 \mathrm{BC}$ (Willcox 2012), and from there was later brought into Europe (Shennan 2018). The idea of a local, European invention of agriculture and animal husbandry was rejected early on, as it became clear that domesticated plant and animal species originated from southwest Asian wild precursors (Conolly et al. 2011; Coward et al. 2008).

Neolithic ways of life spread into Europe along different routes and in different ways (Figs. 1 and 2). Rather than a continuous expansion (Ammerman and CavalliSforza 1971, 1984; Pinhasi et al. 2005), there are distinct periods of expansion to regional haltlines, followed by periods of stagnation and finally renewed expansions (Bocquet-Appel et al. 2012; Brami and Zanotti 2015; Shennan 2009). Around 6500 $\mathrm{BC}$, the Aegean shores were reached by Neolithic settlers, who created communities archaeologically associated with painted pottery traditions and tell settlements, probably derived from Anatolia (Çilingiroğlu 2016; Furholt 2017a; Perlès 2001; Reingruber 2008, 2011; Schoop 2005; Schubert 1999) and connected to the Greek Protosesklo and Sesklo complexes (see Fig. 3; Demoule and Perlès 1993).

Around 6000 to $5800 \mathrm{BC}$, a renewed wave spanned the Balkans north to the southern Carpathian Basin, associated with the the Balkanic Karanovo I-III and Starčevo-Kőrös-Criș "cultures" (Figs. 1 and 3; Bánffy 2019; Domboróczki and Raczky 2010; Luca and Suciu 2011; Oross et al. 2016; Whittle 2007, 2010). Later this Neolithic expansion continued into central Europe, with mostly unpainted but polished and incised pottery surfaces, post-built houses, and extended flat settlements connected to the LBK "culture," which started to spread around 5350 $\mathrm{BC}$ and rapidly populated the fertile loess-covered areas reaching from eastern France to Ukraine by 5200 BC (Bánffy 2019; Bickle and Whittle 2013; Gronenborn 2007; Jakucs et al. 2016; Lüning 2000). This movement was followed by 


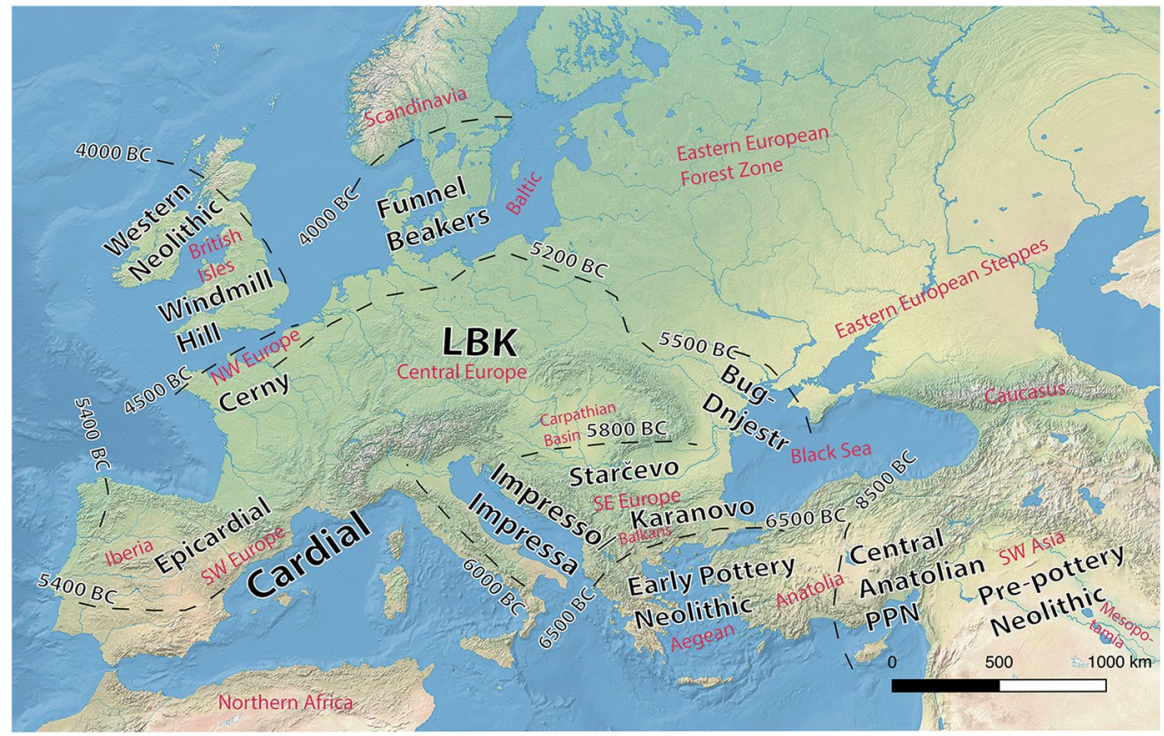

Fig. 1 Map of Europe showing the most frequently used geographical units (red text), illustrating the expansion of Neolithic ways of life into Europe, and displaying the most important archaeological units of classification. Dotted lines indicate significant haltlines between periods of more rapid expansion of Neolithic settlement territories

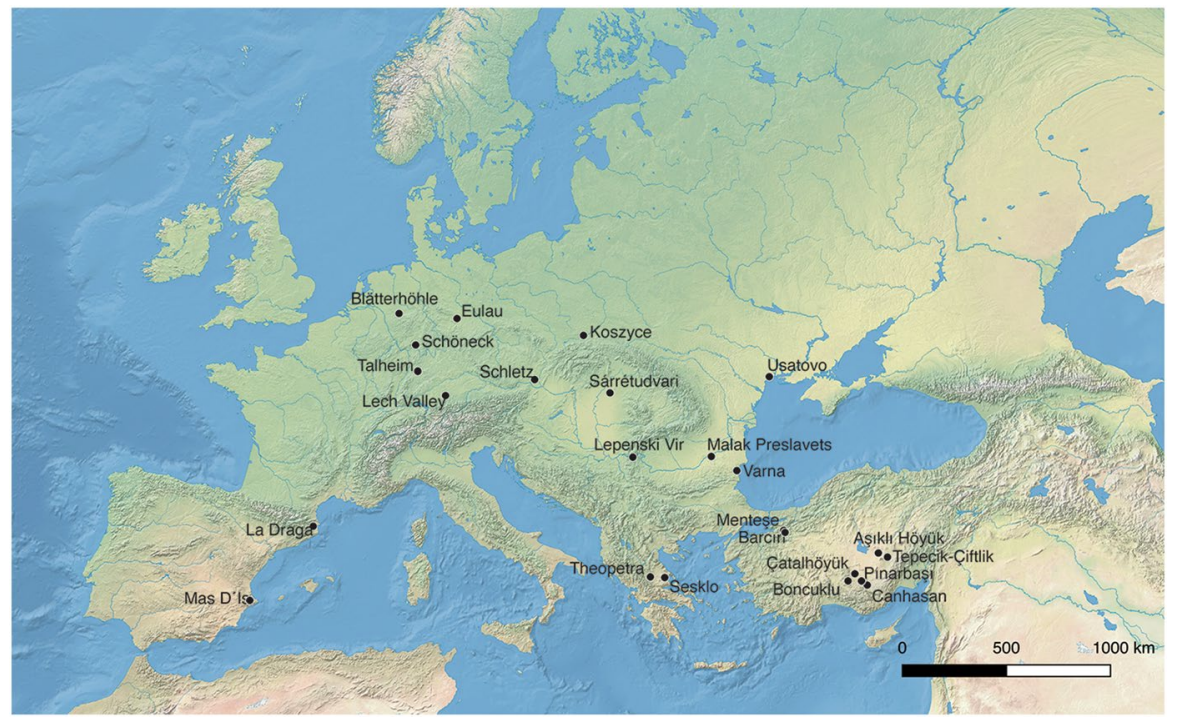

Fig. 2 Map showing the archaeological sites mentioned in the text 


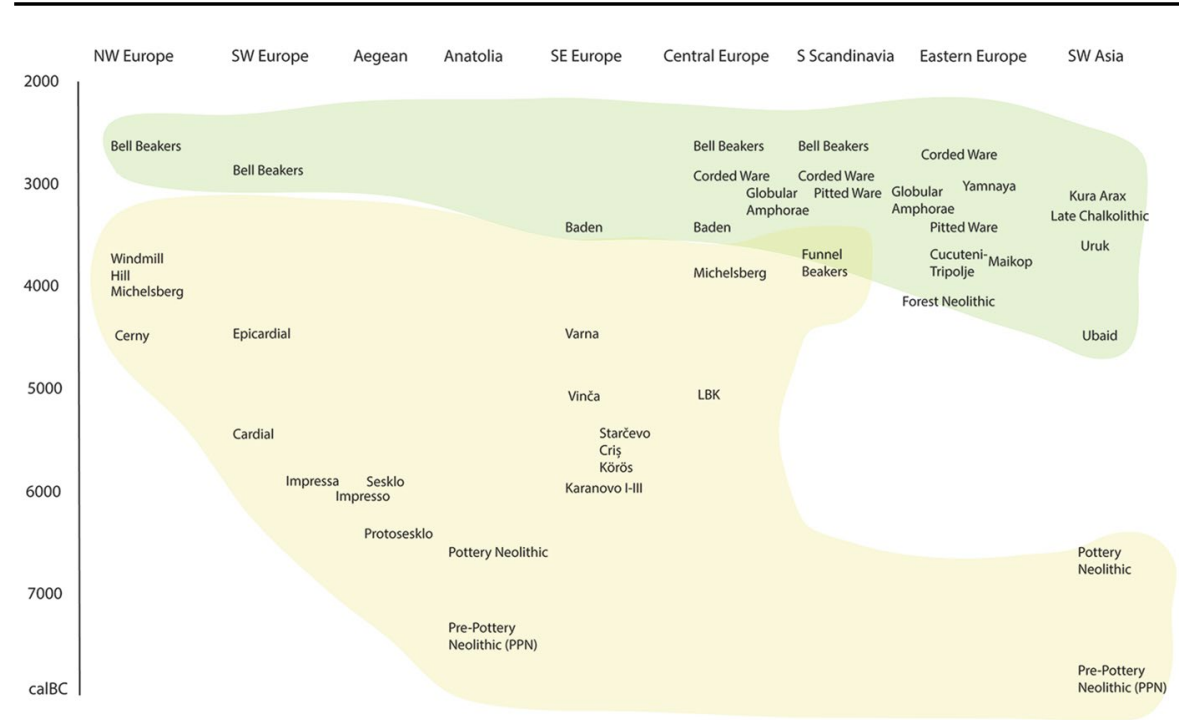

Fig. 3 Sketch of the chronological and regional position of the most important archaeological units mentioned in the text. The two different colors indicate the relevance of these units for the first main part of the text (Neolithic expansion) and the second part (third millennium mobility)

a long pause after $5200 \mathrm{BC}$; northwestern France was not reached until $\sim 4500$ BC (Cerny "culture," see Scarre 2011), and the British Isles (Windmill Hill, see Whittle 1996) and southern Scandinavia (Funnel Beakers: Klassen 2004; Midgley 1992; Müller 2011) not until 4000 BC, all characterized, among other features, by megalithic monuments (Midgley 2008).

The second route of expansion of Neolithic ways of life into Europe followed a maritime route along the northern Mediterranean coast (Figs. 1 and 3; Zilhão 2000), connected with impressed pottery decoration, called Impresso in the eastern Mediterranean (Çilingiroğlu 2016; Müller 1994), Impressa in Italy, and Cardial in the west (van Willigen 2006). This impressed pottery tradition started from southwest Asia and/or the Aegean region around $6000 \mathrm{BC}$ (Çilingiroğlu 2016) and reached the Iberian Peninsula at 5600 BC (Guilaine 2018; Manen et al. 2019; Perrin et al. 2018; Zilhão 2001). While Early Neolithic Greece and Italy show an abundance of houses and villages (Perlès 2001; Robb 2007), most domestic sites during the Early Neolithic period in southern France and the southern part of the Iberian Peninsula are known from cave fillings or from openair sites, which in most cases do not show clear signs of architecture comparable to the eastern European settlements (van Willigen 2006; Zilhão 2000). Exceptions are the lakeside settlement of La Draga in Catalonia (Tarrús 2008) and the Mas D’Is site (Bernabeu Aubán et al. 2003), where the large number of preserved wooden posts are not easily reconstructed as rectangular houses. Overall, when compared to the southeastern European and Italian Early Neolithic, a reduced Neolithic package that excluded substantial houses and villages was introduced in southwestern Europe. 


\section{The Expansion of Neolithic Ways of Life into Europe: The Traditional Debates}

While the routes that spread Neolithic ways of life are more or less undisputed, the manner of the spread is the subject of long-lasting heated debates. Some proposed a slow and steady demic diffusion (Ammerman and Cavalli-Sforza 1971, 1984; Pinhasi et al. 2005); others highlighted episodic expansionary phases, i.e., the frontier model (Biagi et al. 2005), leapfrog models (Zvelebil 1994; Zvelebil and Rowley-Conwy 1984), and rapid, large-scale colonizations (see Borić and Schulting 2017). The role of hunter-gatherers in adopting Neolithic practices or being integrated into Neolithic groups is also envisaged differently (Robb 2013). We are thus far beyond the simplified question - whether the Neolithic economy and ways of life were introduced via migration (of Neolithic communities) or diffusion (local hunter-gatherers adopting them via a transfer of ideas) - that dominated older debates (see Perlès 2001; Robb and Miracle 2007) and were reinforced by the framing of the first new aDNA papers on the subject (Bramanti et al. 2009; Haak et al. 2005, 2010). The package-like appearance of different traits of material culture, settlement organization, and subsistence practices is often taken as a main argument for a more massive migration model (Çilingiroğlu 2005; Özdoğan 1998, 2006, 2011; Shennan et al. 2015). Other colleagues instead highlight continuities from the Mesolithic to the Neolithic period, most clearly visible in the lithic technologies, as arguments for local adaptation or at least as a basis to argue for a Mesolithic contribution to early farming communities (Borić et al. 2019; Cummings and Harris 2011; Kind 1997; Mateiciucová 2008; Tillmann 1993).

In different regions of Europe, the question to what degree migration played a part in Neolithization processes has been treated differently. In southeastern and central Europe most archaeologists highlighted migration as the main mechanism of change (Bánffy and Oross 2010a; Gronenborn 1999, 2005; Lüning 2005; Zimmermann et al. 2005). Only a few dissenting voices pointed to the lithic materials (Mateiciucová 2008; Tillmann 1993) or highlighted evidence of cereal remains in Mesolithic contexts or pollen diagrams (Gehlen 2010). By contrast, in southern Scandinavia (Bergsvik 2012; Fischer 2002; Jensen 2001; Klassen 2004; Østmo 1988; Prescott 1996) and on the British Isles (Bradley 2007; Cummings and Harris 2011; Robb and Miracle 2007; Thomas 1988, 1999), local adaptation of agriculture, pottery styles, and house forms was for a long time the mainstream view. In many of these discussions, we find remnants of the old binary or at least one-dimensional debate around whether or not or to what degree the Neolithic ways of life were introduced by migrants or taken on by locals. In the background of these debates is the monothetic concept of past communities that are by default seen as clearly circumscribed and bounded groups, who either migrated or stayed local, while any alternative to such a binary view is represented by the question to what degree such bounded groups mixed. To view social borders during the Neolithic as fluid and social group compositions as dynamic, as suggested by the anthropology of nonstate, small-scale societies (Cameron 2013), is considered, if at all, exceptional and in need of strong supporting evidence, a position very different from the default assertion of cultural homogeneity and social boundedness (see Furholt 2018a). 


\section{Out of Anatolia: The aDNA Evidence for Early Neolithic Population Movements}

The traditional archaeological debates were heavily affected by the advance of aDNA as a new source of data that started to appear in 2005. One main finding is that the great majority of Neolithic communities in Europe were established by people with genetic lineages going back to Anatolian early Neolithic communities, while the genetic lineages of European hunter-gatherers played a much smaller role. Most aDNA papers that present nuclear DNA data include a principle components analysis (PCA) that displays parts of the variability of a large sample of modern Eurasian individuals (see Lazaridis et al. 2014). The first two components calculated seem to strongly correlate with geography, showing the southwest Asian samples to the right, those from the Caucasus in the upper right, southwestern Europe to the lower left, and northern and northeastern Europe in the upper half (Fig. 4). For a characterization of overall trends in population history, the prehistoric samples are usually projected onto a graph, with clusters named using different types of nomenclature (Eisenmann et al. 2018). Most common is a "mixed nomenclature" that combines geography and supposed subsistence base. Although not unproblematic, I follow this tradition here.

Western European hunter-gatherers (WHG) fall to the left of modern Iberian individuals, while the Early Neolithic individuals (early Anatolian farmers: EAF) are located between the modern inhabitants of southwest Asia and modern southwestern Europeans, close to modern inhabitants of Sardinia. The Neolithic individuals analyzed from western Anatolia form a cluster with the European Early Neolithic individuals in southeastern and central Europe, as well as with those from the Iberian Peninsula (still named EAF). Early on this was interpreted as making the case for the migration of people from southwest Asia or Anatolia into Europe as the main driver of the continent's Neolithization (Bramanti et al. 2009; Brandt et al. 2013; Haak et al. 2005, 2010, 2015; Lazaridis et al. 2014). Recently, it was found that a single 15,000-year-old Epi-Palaeolithic individual from central Anatolian Pinarbaş1 and five individuals from the early central Anatolian Aceramic Neolithic in Boncuklu sort into the same cluster (Feldman et al. 2019). Five individuals from the central Anatolian Early Neolithic site of Tepecik-Çiftlik are found close to this cluster, indicating a local origin of this specific kind of ancestry (Kılınç et al. 2016). From the standpoint of genetic ancestry, Anatolia thus seems to be the main source or at least a major source for almost all Neolithic communities in Europe (Omrak et al. 2016), apart from the eastern European forest and steppe zones. The latter do not, however, constitute Neolithic societies as defined by food production, but huntergatherers who used pottery (Piezonka 2008; Tringham 2014).

The southwest Asian Neolithic ways of life were invented and established, it now seems, by at least two genetically distinct groups of hunter-gatherers, one in the southern Levant, the other in an area that spans Iran to the Caucasus (Broushaki et al. 2016; Lazaridis et al. 2016). Central Anatolia seems to be a region of secondary Neolithization; sedentary settlements appeared first around $8500 \mathrm{BC}$, and after that time, cereal farming and animal husbandry were successively introduced (e.g., Düring 2011, pp. 59-62). The central Anatolian Neolithic populations seem to have strong roots in the local hunter-gatherer populations, with some small degree of 


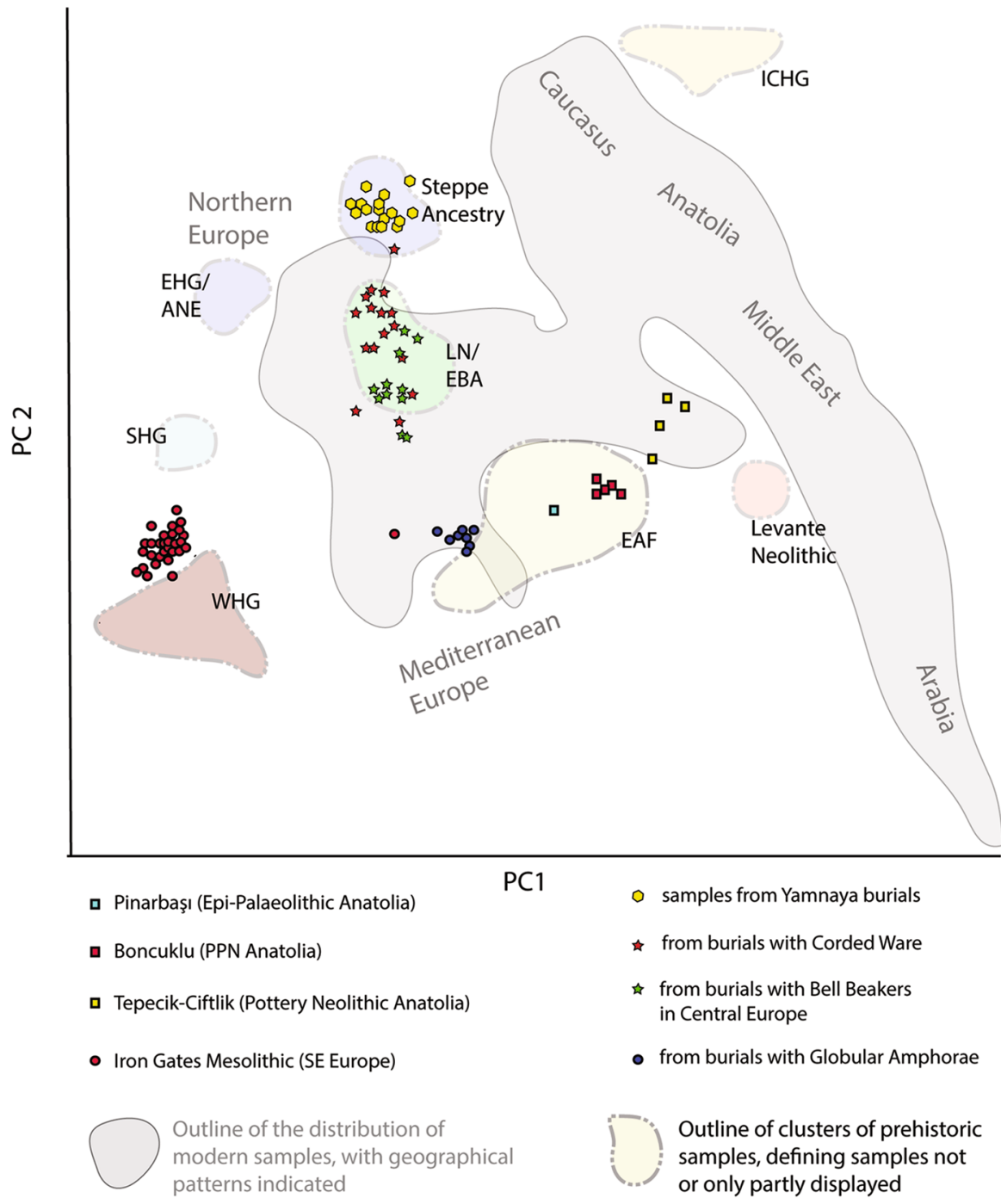

Fig. 4 Simplified representation of a principal component analysis (adapted and altered after Mathieson et al. 2018, extended data figure 1) displaying the main patterns whole genome samples from late Epipalaeolithic/Mesolithic and Neolithic individuals, projected upon 777 modern samples (gray areas). Clusters commonly used are indicated by colored shading: EAF: early Anatolian farmers; WHG: western hunter-gatherers; EHG: eastern hunter-gatherers; SHG: Scandinavian hunter-gatherers; ANE: ancient north Eurasians/Native Americans; ICHG: Iranian Neolithic and Caucasus hunter-gatherers; LN/EBA: Late Neolithic and Early Bronze Age in central Europe, southern Scandinavia and the Carpathian Basin; steppe ancestry was defined with reference to Yamnaya-related samples. Some individual samples connected to archaeological units discussed in the text are shown for illustrative purposes, without being a representative selection 
admixture with populations from the southern Levant, Iran, and the Caucasus (Feldman et al. 2019). After a remarkably long period of spatial stability, largely connected to the "Pre-Pottery Neolithic" (PPN) period, the first larger expansion from central Anatolia westward into western Anatolia and southeastern Europe began around 6600 BC (Fig. 1), mostly connected to the "Pottery Neolithic" period (Brami 2017; Brami and Zanotti 2015; Çilingiroğlu 2012, 2016; Furholt 2017a; Horejs 2016; Horejs et al. 2015; Weninger et al. 2014). These Early Neolithic western Anatolian communities are represented in the archaeogenetic dataset by samples from the sites of Menteşe Höyük and Barcın Höyük, south of the Marmara Sea (Mathieson et al. 2015).

Comparing the early PPN individuals from Boncuklu (central Anatolia) to later ones from Pottery Neolithic Tepecik-Çiftlik (central Anatolia) and Barcın (northwestern Anatolia), as well as central European LBK individuals, Kılınç et al. (2016) found that the Boncuklu individuals most probably derived from a much smaller ancestral population than the other groups. They thus point to a marked rise in genetic intermixture during the Early Neolithic (PPN) period in central Anatolia, later than the individuals from Boncuklu (i.e., 8200-8000 BC) but before the expansionary move (6600 BC). As Mathieson et al. (2018) argue, this could be connected to genetic interaction with other Early Neolithic groups, including those from Iran/ Caucasus and southern Levant.

\section{Adding aDNA Data to the Neolithization Debates}

The new aDNA evidence has been widely perceived as settling the migration versus local adaptation debate. But this clearly misses the point, as this binary question is in itself highly problematic. As Robb (2013) demonstrates, for example, the diversity of social practices and material expressions found among Neolithic communities in Europe is striking and marked, despite the structural similarities that govern them. This indicates that their respective formation histories have to be told by taking more complex and varied factors into account than whether or not people moved. It is thus misleading to present a single narrative, a single process, or a uniform set of factors to explain the archaeological picture of these diverse communities. Instead, it is necessary to study the different regional and local manifestations of Early Neolithic communities in their own right. And what might look as one single continental process is more likely an amalgam of several different processes, movements, and historic developments that took place at many different spatial and temporal scales.

Nevertheless, now having aDNA data available, an obvious new starting point to understand at least some of the underlying processes of human movements is to look at the genetic composition of the Early Neolithic communities in different parts of Europe and to explore how that relates to the social practices studied, with special attention paid to the role of European hunter-gatherers. The genetic composition of Neolithic communities in southeastern Europe is, according to ADMIXTURE analyses, heavily dominated by the component that is defined as early Anatolian farmers (Mathieson et al. 2018). However, given the fact that this component is the one most probably derived from Anatolian hunter-gatherers, any genetic contribution of 
western Anatolian and probably also Greek hunter-gatherers during this expansion would be totally masked if they were genetically similar to those of central Anatolia. While this hypothesis needs to be further tested, it is at least to some degree supported by the fact that two Mesolithic individuals from the Theopetra cave in Thessaly, Greece, are of mtDNA haplogroup K1c, which is most frequently found in EAF individuals (Hofmanová et al. 2016). What is usually referred to as "European hunter-gatherers" are genetic signals from western Europe (WHG), eastern Europe and Siberia (eastern hunter-gatherers, EHG), or Scandinavia (SHG). Only where individuals with this kind of ancestry have interbred with EAFs will their contribution show up in the models. As skeletal material from the Mesolithic is much scarcer than that from the Neolithic, genetic variation among European huntergatherers is probably also underestimated. Among the hunter-gatherers from the Iron Gates, who are modelled mainly as WHG with some small EHG components (see Fig. 4), Mathieson et al. (2018, p. 3) report that they also show an affinity to EAF, with mtDNA haplogroups $\mathrm{H}$ and $\mathrm{K}$, which are unusual for hunter-gatherers; one individual even shows a substantial EAF component in the ADMIXTURE analyses (Mathieson et al. 2018, fig. 1d). Again, this EAF affinity could technically also refer to Aegean or Anatolian hunter-gatherer ancestry. The picture is different at the famous Iron Gates site of Lepenski Vir, where three out of four individuals sequenced are classified as fully or predominantly EAF, while the fourth combines WHG, EHG, and EAF ancestry. The conventional interpretation is that a Mesolithic population settled into a sedentary lifestyle at Lepenski Vir, due to favorable ecological conditions near the Danube River, and later transitioned to a Neolithic economy (Borić 2016; Cook et al. 2002). Isotope analyses had already indicated increased mobility around the transition to a Neolithic economy (Boric and Price 2013), and the individuals with EAF ancestry date to this exact period (6200 to $5600 \mathrm{BC}$ ). They could thus be migrant farmers, but given the argument made above, they could as well represent hunter-gatherers from the southeast. Nevertheless, the case for a fully autochthonous uptake of Neolithic subsistence practices by sedentary fisher-gatherers is severely weakened by the new aDNA evidence.

The possibility of a hidden presence of Anatolian or Aegean hunter-gatherers aside, the impact of WHG and EHG ancestry in individuals from southeastern Neolithic sites is in general low, 0.0-3.0\% (Mathieson et al. 2018). But there are notable exceptions, like the Bulgarian site of Malak Preslavets, where 8 out of 9 individuals had a significantly raised proportion of EHG and WHG ancestry (Mathieson et al. 2018). The reason for the overwhelming dominance of EAF ancestry could lie in significantly different population sizes of early farming versus hunter-gatherer communities (Bocquet-Appel and Bar-Yosef 2008b). Mathieson et al. (2018) argue that places like Malak Preslavets show that the impact of hunter-gatherer ancestry (WHG and EHG) in Neolithic communities was basically determined by their varied regional presence, and not so much by deliberate avoidance. The continuous increase of EHG and WHG ancestry in Neolithic and Copper Age individuals across the continent during the following millennia support this view. This observation, together with the argument of Kilinç et al. (2016) about the continuously rising diversity of the effective ancestral populations toward the Neolithic expansion that began at $6600 \mathrm{BC}$, negates the idea of an expansion process driven solely by 
demographic growth out of a clearly bounded founder population. Rather, it seems to indicate social fluidity and intermixing between early farming communities and between early farming and hunter-gatherer communities.

An interesting aspect here is the sex-bias toward a larger male than female hunter-gatherer contribution to Neolithic communities in central Europe and Iberia (Mathieson et al. 2018), as well as northwestern Europe and Scandinavia (SánchezQuinto et al. 2019) but not in southeastern Europe (Mathieson et al. 2018). A possible explanation for this would be matrilocality, but most studies that compare genetic diversity between the sexes and more recent biological kinship analyses of collective burials point to patrilocality (Haak et al. 2008; Sánchez-Quinto et al. 2019; Szécsényi-Nagy et al. 2015). However, there is no reason to assume one overall mode of social organization for all Neolithic communities in Europe. It is conceivable and not far-fetched to assume different cultural regimes for regulating (or not regulating) sexual reproduction in different periods and regions during the Neolithic.

\section{What Started and Drove the Expansion of Neolithic Communities into Europe?}

Shennan (2018) recently argued that the main cause for Neolithic expansion into Europe was population growth, which led to demic diffusion, mainly in the form of leapfrog colonization, where a subset of a population set out to locate and then settle in an often-distant area suitable for farming. Population growth as a consequence of the new subsistence regime is supported by the overall dataset (Bocquet-Appel and Bar-Yosef 2008a), but there are no indications to assume population pressure reaching regional carrying capacities was a widespread phenomenon in the Neolithic. Thus, more factors than population growth have to be taken into account to explain the continuous and large-scale expansion of Neolithic ways of life into Europe, both social, in the form of inner social conflicts (Leppard 2014), and ecological, in the form of climate instability (Weninger et al. 2014).

When Neolithic communities started out from central and perhaps south-central Anatolia around 6600 BC, they looked back on more than 1000 years of life in PPN "megasites," large clay-built tell settlements that emphasized a spatially fixed and concentrated domestic sphere (Düring 2011; Furholt 2017a, b). These communities' ideology, it has been argued, circled around the idea of valuing a specific place, visible in the habit of building new houses directly on top of older ones (Hodder 2006; Hodder and Pels 2010; Rosenstock 2009). This control of space and emphasis on spatial stability could be argued to be a useful, if not necessary, condition for establishing a new subsistence strategy built on agriculture. It is necessary to regulate social relations and to define some restrictions of access to land and resources in an economic system that requires storage of seeds and potentially creates a surplus of food (e.g., a delayed-return system, see Furholt et al. 2020; Woodburn 1982). In larger settlement concentrations, it is conceivable that there is a high potential for conflicts over resource distribution, between different interests and social obligations, and between autonomy and community solidarity (e.g., Furholt et al. 2020; Leppard 2014). 
The central Anatolian tell settlements (represented by, among others, Aş1klı Höyük, Canhasan, Boncuklu and Çatalhöyük, see Düring 2011), which we now know seem to represent at least a part of the source of the expansion of Neolithic ways of life into Europe, are a decidedly extreme version of settlement concentration, regulation, and circumscription of space; the ideological charging of domestic space with symbolic capital is most visible in the iconic site of Çatalhöyük (Düring 2011; Hodder and Pels 2010; Marciniak et al. 2015). This system of concentrated tell settlements in central Anatolia was in place for an extremely long period of time, established sometime after $8500 \mathrm{BC}$, before the renewed expansion westward that started around 6600 BC (Brami 2017; Brami and Zanotti 2015; Düring 2013).

One could argue that this prolonged spatial stability was possible only as long as the potential for conflict inherent in Neolithic economies was held down by an ideology that backed an extreme control of social space (Furholt 2017a; Furholt et al. 2020). However, this control seems to have become less effective during the later phases of Çatalhöyük (Hodder 2014). Most visibly after 6400 BC, household autonomy was strengthened (Marciniak et al. 2015) at the cost of settlement-wide social institutions, which are visible in more variable forms of architecture. At the same time, a renewed expansion of Neolithic ways of life rapidly reached western Anatolia and crossed the Aegean into eastern Greece. During this process the extreme concentration of settlement in pueblo-style wall-to-wall agglomerations known from central Anatolia was in most cases replaced by more-open and more-diverse patterns of house placements and building techniques (Furholt 2016, 2017b), again indicating more autonomy for the household (Kotsakis 2006) at the cost of village uniformity. In other words, there is some evidence that changes in the sociopolitical organization of the early farming communities in central and western Anatolia coincided with the first expansion after roughly 1500 years of stagnation. Those social changes might have been connected to, or triggered by, growing populations, at least in Çatalhöyük (Shennan 2018), and disruptive external factors, such as climate fluctuations (Weninger et al. 2014), but the result was a significant weakening of the system of spatial stability that kept concentrated communities together and the emergence of social fission - the possibility for a subunit to leave a community - as a viable and frequent social strategy (Leppard 2014).

This new social model presents an important factor that facilitated the further expansion of Neolithic settlement territory in Europe. A scenario like the fission and fusion model proposed by Leppard (2014) and discussed by Hofmann (2020) seems to both describe a social setting that plausibly contributed to expansion and explain the rising diversification of the Neolithic gene pool. A main driver of expansion in this model of the new mixed farming economy is a growing tension between household autonomy in producing and storing essential resources and the social imperatives of sharing and communality. Leppard (2014) argues that internal social conflict over resource distribution created fissile social communities for which secession and colonization of new, unused fertile areas were a potential solution (for similar models regarding other regions of Europe, see Hofmann 2016; Zilhão 2000). Such a social fission could then very well be followed by the social fusion of migrating groups from different origins. In addition, a higher degree of social fluidity as a result of secession and migration might manifest itself in other forms of population 
circulation between residential communities (e.g., Schachner 2012). This population circulation might have included local hunter-gatherers, wherever they were present. Studies of isotopic signals that reflect patterns of mobility and subsistence practices as well as genetic data that indicate the diversity of biological lineages in distinct Early Neolithic settlement communities have largely supported this view of socially heterogeneous, fluid residence groups (Bentley et al. 2002, 2008, 2012; Brandt et al. 2014; Zvelebil and Pettitt 2012).

The fission and fusion/population circulation model also explains best the empirical fact that the Early Neolithic in Europe is characterized by the occurrence of widespread regions of similar material culture, the so-called "archaeological cultures." The culture-historical tradition, which views uniform material culture as a quasi-natural trait of ethnic groups and still dominates the majority of research in southeastern Europe, has more or less diverted attention from this remarkable phenomenon. However, in the context of expanding Neolithic communities, regional similarity of pottery styles, and other traits of material culture over many generations, even centuries under the condition of local, self-supplying production, is best explained by frequent population circulation and intermixture between communities, creating translocal social ties (Furholt 2018a).

\section{Different Variants of Neolithic Societies in Europe}

In accordance with the fission and fusion models discussed above, the establishment of "Neolithic ways of life" is a complex process with many locally and regionally distinct histories, in which, from an archaeological point of view, migrants and locals and new and old traditions interacted in different ways (e.g., for southeastern Europe: Borić et al. 2019; Borić and Schulting 2017; Orton 2012; Orton et al. 2016; Tringham 2014). This variability of practices that we know from the archaeological record cannot be explained by looking solely at aDNA data. It should be explored by a close contextual evaluation and comparison of specific local examples in different regions that go beyond the scope of this article.

Beyond such a level of detail, differences can also be summed up as large-scale regional trends. There is a long tradition in contrasting larger groups of regionally and archaeologically connected Neolithic societies in Europe, most prominently the "Danubian Neolithic" (e.g., Childe 1929)—i.e., the southeastern European Neolithic and the central European LBK-as opposed to the northwestern European, or "Atlantic" Neolithic (e.g., Sherratt 1990). While this division into a Danubian and Atlantic Neolithic has always been a simplification, it can be useful, because these two (artificial) units roughly correspond with the two main routes of expansion of Neolithic ways of life out of Anatolia.

For the "Danubian Neolithic," aDNA studies have found that there seems to be no large difference between the gene pools connected to the southeast European Early Neolithic and central European LBK, which suggests that the latter basically represents people who left Starčevo communities and further pushed the boundaries of Neolithic ways of life to the north, with new social strategies and types of material expression, while others remained in the Balkan region and formed Vinča-type 
settlements (Mathieson et al. 2018; Szécsényi-Nagy et al. 2015). Involvement of local hunter-gatherers was as low in the central European LBK contexts as in southeastern Europe, probably again reflecting the low number of hunter-gatherers around. While the formative period of the LBK started around $5600 \mathrm{BC}$ in western Hungary and eastern Austria in a context that preserved several elements of Starčevo material culture, LBK expansion to the north started around $5350 \mathrm{BC}$ and rapidly covered and filled large regions of central Europe (Bánffy 2004, 2019; Bánffy and Oross 2010b; Denaire et al. 2017; Jakucs et al. 2016; Stäuble 1995; Whittle 2018, p. 187). After reaching the boundaries of the fertile loess areas of central Europe to the north and west, however, Neolithic expansion came to a halt around $5200 \mathrm{BC}$ for 700-1000 years (Fig. 1; Gronenborn 1999). In addition, LBK settlers who entered the eastern areas of western Europe met the successors of the other, maritime route of Neolithic expansion along the Mediterranean coasts.

A very different development had taken place in western Europe. The Mediterranean expansion of Neolithic settlements was fueled by an influx of people with a similar ancestry to those who peopled southeastern and central Europe (e.g., Valdiosera et al. 2018). Around 5600 BC, the Iberian Peninsula was reached by Neolithic populations. Valdiosera et al. (2018) argue that the Iberian Early Neolithic population showed a lower genetic diversity regarding their effective ancestral population than those in southeastern and central Europe, although they also have their roots in the same Anatolian areas. This could mean that the people using the maritime route from Anatolia westward derived from a smaller and probably different subset of the Anatolian populations than the other Early Neolithic Europeans. As occurred in southeastern Europe, the genetic record suggests the mixture of people with EAF and WHG ancestry, albeit varying regionally (Szécsényi-Nagy et al. 2017), probably again corresponding to the different numbers of hunter-gatherers around (SánchezQuinto et al. 2019). The incorporation of WHG ancestry in Iberian Neolithic communities was more substantial and rapid than in southeastern and central Europe, with levels of over $20 \%$ in the admixture analyses of the Early, Middle and Late Neolithic and Chalcolithic periods. This probably did not impact their subsistence patterns, as SIA show a dominant terrestrial diet during all periods since the Early Neolithic (Valdiosera et al. 2018), irrespective of the proportion of hunter-gathererderived genetic ancestry. This is consistent with the archaeological evidence, which shows that the Mediterranean Neolithic expansion route did involve the spread of domesticated plants and animals, together with the Impressed and Cardial pottery traditions. However, as a clear contrast to the southeastern European Neolithic, the western Mediterranean Neolithic "package" of Iberia did not include a substantial number of settlements that resemble types known from southwest Asia, the Balkans, or Italy.

The Iberian Neolithic shares an important characteristic with other parts of the Atlantic coastlands, western France, the British Isles, and southern Scandinavia; starting in the fifth millennium BC, megalithic monuments, most of them connected to burial mounds but also enclosed ritual areas (cromlechs) or alignments, were constructed in these regions in large numbers (Midgley 2008; Scarre 2011). Due to the durability of the stone-built components of these monuments, this "Atlantic" complex is often referred to as the "megalithic culture," or cultures. Ancient DNA 
analyses of megalithic graves in Ireland, Scotland, Sweden (Sánchez-Quinto et al. 2019), and northern Germany (Immel et al. 2019) show that biological relatedness probably dominated kinship structures, which determined who was buried in which megalithic grave, and that such kinship was-at least in the studied samples-patrilocal and could connect several megalithic graves (Sánchez-Quinto et al. 2019).

Although one should be cautious in generalizing too much over such a large area, it might be justified to argue that, in contrast to the southeastern and central European (i.e., Childe's Danubian) Neolithic, the Atlantic Neolithic was characterized by the central importance of local and regional gathering places and ritual activities outside of residential places. Settlements and house structures in this region have so far been much less visible archaeologically. However, in recent years, refined research strategies have started to change this picture and reveal more evidence for Neolithic settlement structures in northwestern Europe. In western France, a variety of timber and clay-built houses and enclosures have been found (Laporte et al. 2016). On the British Isles, timber buildings have now increasingly been dated to an early period of the Neolithic (Whittle et al. 2011). Nevertheless, there remains an overall difference between the abundance of houses and villages in the context of the Danubian central and southeastern European Neolithic and the Atlantic variant of Neolithic communities, which comprise more autonomous small groups, possibly single farms or small hamlets, that were connected through regular encounters at monuments of local and regional significance (Sherratt 1990).

Yet there are also parallels and convergences between those larger regional traditions. For example, at the end of the fourth millennium, the village and longhouse tradition in central Europe largely disappeared, and new phenomena, like the Michelsberg phenomenon (Fig. 3), have limited finds of houses and villages, similar to the Atlantic tradition (Beau et al. 2017; Jeunesse 2010). This reminds us that the old concept of a Danubian versus an Atlantic Neolithic tradition has heuristic value only when it is restricted to the Early Neolithic period, where it can be used to refer to the two major routes of Neolithic expansion into Europe.

\section{Reluctant Hunter-Gatherers?}

The contribution of hunter-gatherer ancestry (WHG, SHG) to Neolithic populations in Ireland, Scotland (Sánchez-Quinto et al. 2019), and southern Scandinavia (Skoglund et al. 2014) in the fourth millennium BC is substantial, around 20-30\%, similar to the Iberian situation of the sixth and fifth millennia BC. Although there was much smaller contributions of hunter-gatherer-ancestry (WHG, EHG) during the Early Neolithic of southeastern and central Europe (sixth and fifth millennium BC), by $4000 \mathrm{BC}$ this regional difference ceased to exist, due to a steady accumulation of WHG and EHG ancestry over the centuries (Mathieson et al. 2018). However, what really was surprising was the dominance of Anatolian ancestry (EAF) in all the Neolithic populations, even in Scandinavia, where, due to signs of continuity in material culture, settlement locations, and subsistence practices, the archaeological debates had for decades been dominated by the view that Late Mesolithic communities took up Neolithic 
practices, transforming themselves into farmers (Fischer 2002; Jensen 2001; but see Sørensen 2014). While the introduction of farming in southern Scandinavia was preceded by long-lasting contacts between local hunter-gatherers and their southern Neolithic neighbors (Krause-Kyora et al. 2013; Price and Gebauer 1992) without much biological intermixture, a significant influx of people with established Neolithic ways of life obviously played a crucial role in the subsequent Neolithization of this area, as in all other regions in Europe. EAF ancestry is even more dominant in the gene pool of British Early Neolithic individuals (Brace et al. 2019).

These findings change our understanding of the establishment of Neolithic ways of life in western Eurasia. Outside of the southwest Asian "Fertile Crescent" and central Anatolia, it seems that nowhere were hunter-gatherers willing or able to adopt agriculture and connected forms of social organization without a substantial contribution of migrants who could look back on generations or centuries of adjustment to these new economic and social regimes. While the central Anatolian data show that this was not a universally human pattern, it does now seem that the Mesolithic communities in Europe shared structural conditions of their way of life that effectively barred them from adopting a food-producing lifestyle. This seems even more unexpected given that the Mesolithic in Europe is viewed by many scholars as a period in which people became more closely linked to their specific environments and territories (Otte 2009); especially towards the end of this period many hunter-gatherer communities are thought to have become almost sedentary, semi-sedentary, or fuzzily sedentary (Bergsvik 2012). They invested more in landscape transformation, and in different parts of Europe Late Mesolithic people adopted or experimented with domesticates (Erny-Rodmann et al. 1997; Gehlen and Schön 2003; Krause-Kyora et al. 2013; critically Behre 2007; Richard 2004), without fully transforming into farming and herding societies. It would thus seem that the late hunter-gatherers had all the prerequisites to independently adopt these new practices and innovations. There is no good argument to conclude that not a single European hunter-gatherer group would have been capable of adopting farming or animal husbandry strategies, when those of central Anatolia very well were. It seems more likely to assume ideological reasons, an incompatibility of worldviews and value systems, maybe even an active rejection of farming lifestyles (as argued by Klassen 2004), at least by most hunter-gatherer communities. There is at least one concrete instance, the German "Blätterhöhle" of hunter-gatherers who lived side by side with farmers for millennia without much biological admixture (Bollongino et al. 2013). On the other hand, as discussed, we have evidence for hunter-gatherer individuals joining existing farming communities, which over time accumulated a considerable proportion of hunter-gatherer ancestry. It seems that, from the perspective of a European hunter-gatherer, the prerequisite for conversion to a Neolithic lifestyle was an intensive personal contact, maybe even integration into a farmer community. Such an integration might have been facilitated by the socially fluid and thus open character of Early Neolithic residence groups that resulted from the fission and fusion/population circulation model discussed above. 


\section{Summing Up the Neolithic Expansion into Europe}

It is now clear that what is commonly referred to as a migration of Anatolian farmers into Europe really represents a broad amalgam of different developments, different mechanisms of mobility and social change, and admixture of groups and adaptations to new environments. This variability does not contradict the validity of overall trends, such as demographic growth and inner-social conflict caused by the Neolithic mode of production as decisive factors that drove the expansion, or the reluctance, of hunter-gatherer groups to adopt Neolithic ways of life, unless triggered by intensive contact with substantial numbers of people socialized within a Neolithic context. It might even be that integration into pre-existing farming communities is the only way in which a European hunter-gatherer really converted to a Neolithic lifestyle. To refer to such continent-wide observations does not reduce the importance of the regional and local histories and the social processes that we can observe at different scales, mostly using archaeological materials but also increasingly the molecular biological evidence we have at our disposal.

\section{The Third Millennium BC in Europe}

\section{The Steppe Impact in the Third Millennium: The Archaeological Material}

The second major change in the European gene pool took place in the third millennium BC. Different from the periods before, the archaeological material of third millennium in most parts of Europe shows peculiar characteristics. The most striking element is the presence of certain artifacts or sets of artifacts and practices with an extremely wide area of distribution. This is especially the case with what is called Corded Ware and Bell Beakers, but also with Yamnaya burials (Figs. 3 and 5).

Corded Ware (see Furholt 2014) is a label that refers to a set of vessel types often decorated by cord impressions, most prominently the Corded Beaker, but also stone axes with shaft holes, which, given their shape and association with male graves, are referred to as "battle axes" (Fig. 6). This set of vessels and items date to 2900-2000 BC and is found from Norway to Switzerland, and from the Netherlands to Moscow, thus covering central Europe, southern Scandinavia, and the northern part of eastern Europe (Fig. 5). Bell Beakers (Czebreszuk 2014; Fokkens and Nicolis 2012; Martínez and Salanova 2015; Vander Linden 2006) refer to fine-ware bell-shaped beakers, which are often found in combination with stone or copper daggers and a set of archery equipment (Fig. 6), dating from 2700 $\mathrm{BC}$ in Iberia, and from 2500 to $1800 \mathrm{BC}$ in Morocco to Scotland, Sicily to southwest Norway, and Denmark to Hungary, thus covering the western part of Europe and overlapping with Corded Ware in central Europe and southern Scandinavia (Fig. 5). Yamnaya (Kaiser 2019; Merpert 1974) is defined by a specific set of burial rituals, namely pit burials, oval or rectangular in shape, that mostly contain single burials in supine, crouched positions, or lying on their side, ochre sprinkled over the dead, and a burial mound, the so-called "kurgan" (Kaiser 2019). There are many different typo-chronological systems that are not yet backed up 


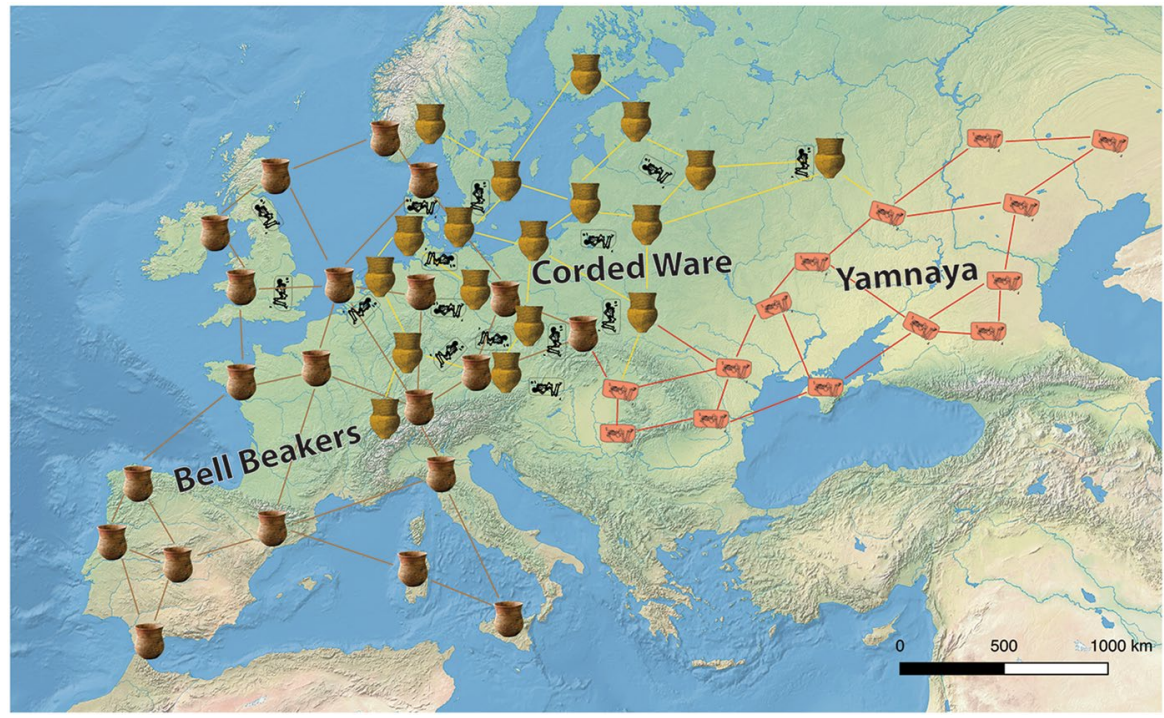

Fig. 5 Map of Europe showing the spatial distributions of the three most prominent archaeological units during the 3rd millennium BC, Yamnaya, Corded Ware, and Bell Beakers. The newly emerging single burial complex intersects Corded Ware and Bell Beakers

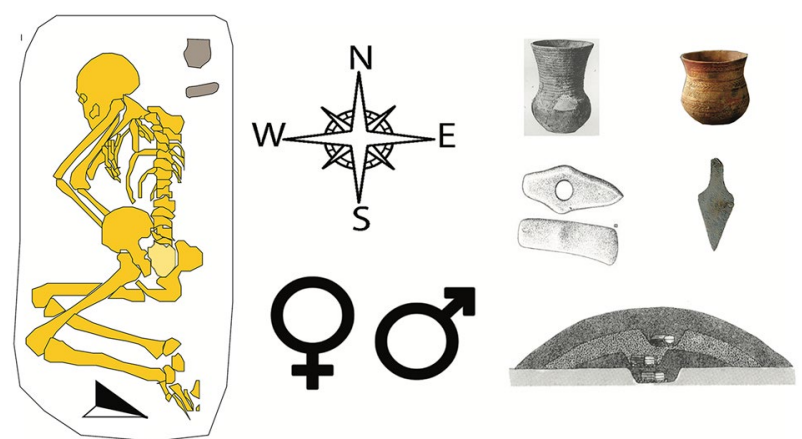

Fig. 6 The main elements of the new, 3rd millennium single burial complex in Europe (after Furholt 2019a): individual aggrandizement (the single burial in a crouched position, under a burial mound), male warriorhood (specialized weapons in male graves), gender differentiation, (reflected by body orientation rules). Drinking vessels of different forms also are prominent: Corded Beakers, Bell Beakers, or Bronze Age cups

by a sufficient number of C14-Dates. In a recent review, Kaiser (2019) tentatively speaks of a period with "early Yamnaya cultures," parallel to late Maikop burials, dating to 3400 to $3000 \mathrm{BC}$, and a "Yamnaya culture" proper, dating between 3000 and 2350 BC (Kaiser 2019, p. 7). It is the later "Yamnaya culture" that shows the wide distribution from the southern Urals to the Carpathians and subsequently beyond (Fig. 5), now commonly connected to migration (e.g., Heyd 2017). 
The main problem and source of confusion with these three archaeological units-Yamnaya, Corded Ware, and Bell Beakers-is that they have traditionally been conceptualized using the model of "archaeological culture," as discussed in the introduction. This has led, repeatedly, to a faulty reification of these units of classification to represent distinct culturally uniform groups of people (see Furholt 2014). This reification has dominated archaeological discourse during the 20th centurywith an interlude by processual archaeologists such as Clarke (1970) and Shennan (1976) — and has unfortunately infected the migration discourse connected to the new aDNA data presented since 2015 (Allentoft et al. 2015; Haak et al. 2015). The problem with the application of the archaeological culture model to these three units is even more obvious than for the Early Neolithic period discussed above. To use the archaeological culture model for those units, say, the LBK, to impose a coherence of specific forms of material culture with specific forms of houses, settlement patterns, burial rites, etc., is a stark simplification, but it is not such a blatant misrepresentation as it is for Yamnaya, Corded Ware, and Bell Beakers.

To start with Corded Ware, this kind of material is associated with the most different kinds of societies thinkable in the third millennium BC, from lakeshore village people in Switzerland (Suter 2017), Jutlandic heath pastoralists (Hübner 2005), and people most probably still mainly occupied with hunting and gathering in southern Norway (Prescott 1996; Prescott and Glørstad 2015), Finland, and the Baltic states (Ahola and Heyd 2020). It is connected to single graves with gender differentiation under barrows in some regions, mostly central Europe, southern Scandinavia, and northwest Russia, as well as to megalithic graves in Denmark and northern Germany; in a third set of regions it is found rarely in burials, and instead mostly in settlement contexts, namely in Switzerland, coastal Netherlands, the Baltic states, Norway, and Finland (Furholt 2019a). Also, Corded Ware vessels and battle axes are associated with other, regionally diverse types of material culture, and even the defining pottery vessels show much more regional variability than is usually mentioned (Furholt 2014). The result is a cognitive dissonance between the archaeological culture model with its supposedly homogeneous, uniform content and the actual data. The presence of similar types of pottery and tools and burial practices over thousands of kilometers is an extremely interesting pattern, but it is not well represented by a monothetic classification at the core of the "archaeological culture," as the patterns of association between pottery styles, tool types, and specific variants of burial rituals are very diverse across the different regions usually subsumed under Corded Ware (Furholt 2019a).

The setting of the Bell Beaker phenomenon is in many respects similar to the setting just described for Corded Ware (Vander Linden 2006, 2007). Bell Beakers have traditionally been portrayed as sets of artifacts that are found as transregional elements in explicitly diverse regional settings, including regionally specific "accompanying pottery" (Besse 2003, 2004). Bell Beaker material culture is found in stone-built fortified settlements with metal production on the Iberian Peninsula (Kunst 2001, 2007); in megalithic graves, caves, and artificial caves or structures resembling tholos graves in France and Italy; single graves with or without gender differentiation on the British Isles and in central Europe (Fokkens and Nicolis 2012; Martínez and Salanova 2015)—here overlapping with Corded Ware burials (Furholt 
2019a); and only in settlements in Jutland and cremation burials in Hungary (Vander Linden 2006).

Finally, the Yamnaya culture is defined solely on the basis of burial customs (Merpert 1974). The current chronological and typological systems are complicated by the fact that there is considerable variation in burial traits and considerable overlap with differently labelled, yet rather similar, burial groups of the preceding and contemporary parallel burial complexes of the Copper Age (Kaiser 2019). Yamnaya burials are seen as part of a long steppe burial tradition that started with the fifth millennium "Early Ocre Graves" (Govedarica 2004). Yamnaya burials themselves are variable, and Merpert (1974) defined nine different regional variants. Also, there is no set of typical Yamnaya grave goods as there is with Corded Ware and Bell Beakers; instead regionally typical objects often were put into the graves, although $80 \%$ of burials do not have (preserved) grave goods at all (Kaiser 2019).

All three units of classification (Yamnaya, Corded Ware, and Bell Beakers) are not compatible with the monothetic archaeological culture concept. This is also true for most other archaeological units of this epoch, for example, the Baden culture (3600-2900 BC, see Furholt 2008, 2009) or the Globular Amphora culture (3200-2600 BC, see Szmyt 1999; Woidich 2014), where transregional phenomena also are superimposed on regionally diverse contexts.

\section{Early Debates on Migration in the Third millennium BC}

Traditionally, Corded Ware was seen, by Kossinna and his contemporaries, as the result of a massive migration that brought Indo-European languages into Europe. The source from which this migration was claimed to have started was either southern Scandinavia or Germany-as Kossinna (1910) tried to evoke Germanic or "Aryan" superiority—or the eastern European steppes (Childe 1925; Myres 1911). Later, Gimbutas $(1979,1991)$ famously invoked several steppe invasions of the "Kurgan people" into "Old Europe," bringing war, patriarchy, and inequality to the peaceful, egalitarian, sophisticated Neolithic societies, the last of which she identified with the Yamnaya-Corded Ware link.

The migration narrative fell out of favor in the context of processual archaeology, in which inner-social transformations were highlighted and Corded Ware and Bell Beakers were conceptualized as "packages" of symbols related to social groups and ideologies (Clarke 1970; Damm 1991; Furholt 2003; Müller 2002; Shennan 1976; Strahm 2002). However, when Kristiansen (1989) and Anthony (1990) revived migration as an explanatory framework, they chose the Jutlandish Single Grave culture - a Corded Ware subunit — and the Yamnaya culture as examples. Nevertheless, the archaeological mainstream remained highly skeptical of migration, with a few notable exceptions (Burmeister 2000; Prien 2005), until the aDNA studies were published in 2015.

The Indo-European question has also remained contentious in archaeology (e.g., Prescott 2013). The problem is that since the early days of Kossinna, the search for Indo-European languages has been connected to essentialist ideas that equate archaeological cultures, ethnic identities, and languages (Hansen 2019). If one 
acknowledges that the relation between language, identities, and material culture is much more complex, situational, and fluid, the connection between archaeology and the search for past languages becomes hard to conduct practically (Demoule 2014).

\section{The Renewed Migration Debate after 2015}

What was found in the aDNA data record of third millennium BC central Europe was a new genetic component, now commonly referred to as "steppe ancestry" (Fig. 4), which is preferred over the initial "Yamnaya ancestry." Haak et al. (2015) had targeted four Corded Ware individuals from central Germany and found, using a PCA, that they had close genetic similarity to a group of Yamnaya burials from Russia. Indeed, all samples from central and northern Europe that date later than 3000 BC formed a cluster (Fig 4: LN/EBA) clearly separated from all Early and Middle Neolithic individuals (EAF) that date prior to $3000 \mathrm{BC}$; this new cluster was located in between the EAF and the steppe ancestry clusters. These findings were spectacular, yet, as criticized earlier (Furholt 2018b), the model used to explain them was taken directly from the traditional, culture-historical discourse, without considering the current state of anthropological and archaeological research. The third millennium archaeological cultures were, as in almost all other aDNA papers, taken to represent distinct biological populations, which created a narrative about a mass migration of a Yamnaya population into Europe that formed the Corded Ware population. Allentoft et al. (2015) generally confirmed the Haak et al. findings and proposed a similar kind of narrative.

What is more, Olalde et al. (2018) published a large set of Bell Beaker samples, which showed that the majority of the eastern Bell Beakers (in Germany, Czech Republic, Netherlands, England, and Scotland) also carried large portions of steppe ancestry, in contrast to individuals connected to western Bell Beaker contexts (in France, Italy, Spain, and Portugal), who for several centuries carried much less or no steppe ancestry, which suggests an ongoing migration stream not congruent with the borders of archaeological units of classification. Only after 2200 BC did steppe ancestry become dominant on the Iberian Peninsula (Olalde et al. 2019).

\section{The Nature of Steppe Ancestry: Rejecting the One-Directional Migration Hypothesis}

It is worth looking more closely at this genetic "steppe ancestry" element. In the admixture analyses of Haak et al., the samples from Yamnaya burials were either taken as a single component (Haak et al. 2015, fig. 3) or modelled as a mixture of mainly two components, namely eastern hunter gatherers (EHG) and a second component that they identify as "... a type of Near Eastern ancestry different from that which was introduced by early farmers" (Haak et al. 2015). The characterization of this latter component was later confirmed by Lazaridis et al. (2016) and Broushaki et al. (2016) who, as discussed earlier, found clear genetic differences between individuals from the southern Levant and Anatolia, and the Iranian Zagros Mountains. The latter, being genetically close to hunter-gatherers from the Caucasus region, also 
expanded to the north into the Eurasian steppes. The individuals in the Yamnaya burials are modelled as a mixture between this Iranian Neolithic/Caucasus huntergatherer (ICHG, see Fig. 4) component and the EHG component. Wang et al. (2019) investigated more deeply the history of the formation of populations north and south of the Caucasus. They found a distinct and stable genetic difference between steppe populations north of the Caucasus and the Caucasian mountain populations from the late fifth to the second millennium $\mathrm{BC}$ that cut through the archaeological culture labels (Figs. 3 and 7). The Caucasian populations, irrespective of whether they were archaeologically associated with "Kura-Arax" or "Maikop" are modelled as a mixture of the Iranian Neolithic/Caucasus hunter-gatherer component (ICHG) and the Anatolian farmers component (EAF, see also Skourtanioti et al. 2020).

The pre-Yamnaya Maikop individuals north of the Caucasus have a similar genetic composition, only lacking the EAF component present in Caucasian Maikop and Kura-Arax individuals. These Maikop individuals from north of the Caucasus are best modelled as a mixture between ICHG, EHG, and a third component, namely ancient north Eurasian/Native American (ANE). Yamnaya individuals from the steppe (i.e., north of the Caucasus) are then very similar to the Maikop individuals north of the Caucasus, even though they lack the ANE component. Wang et al.

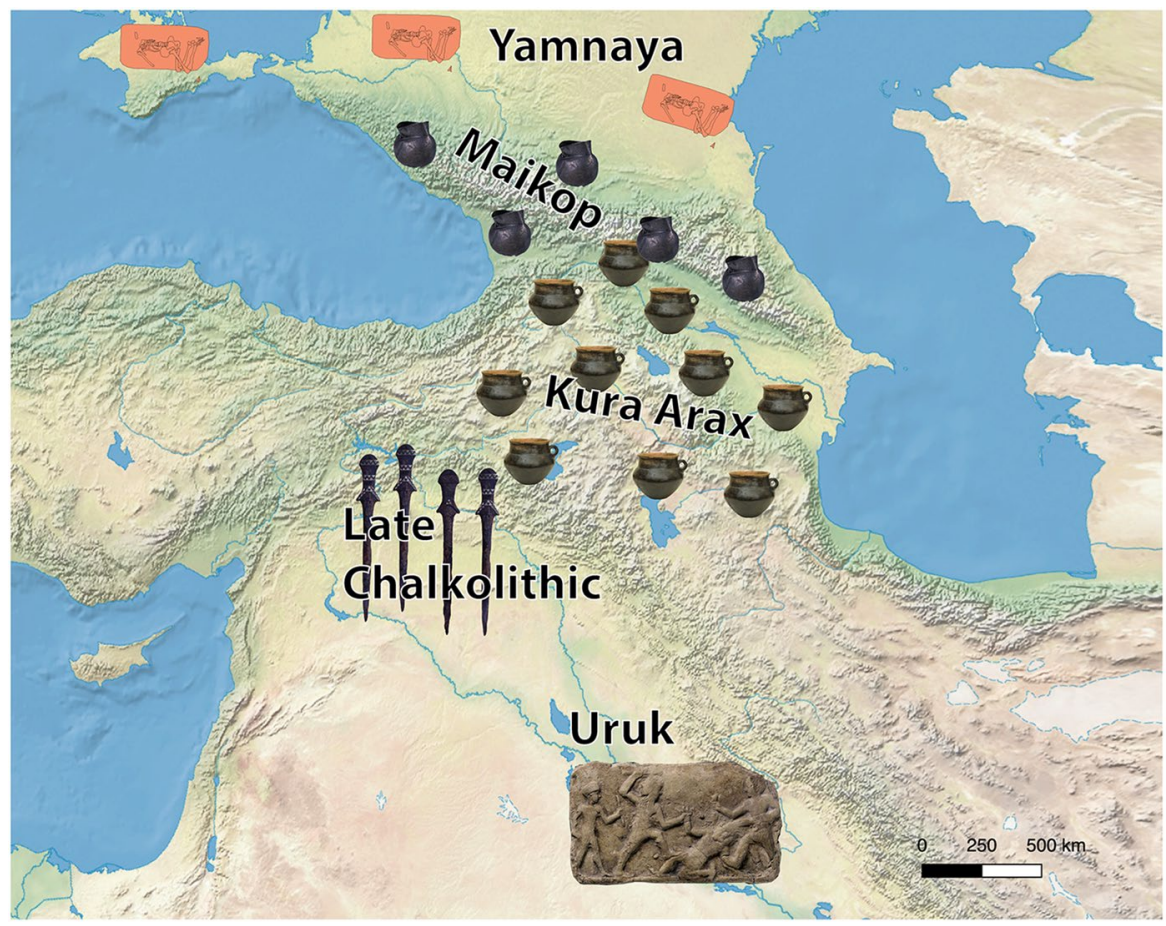

Fig. 7 The archaeological units of classification in the Caucasus region and southwest Asia in the late fourth millennium BC, indicating the connection between Mesopotamian urbanization processes and communities of the Caucasus and steppe regions 
(2019) find a distinct homogeneity in all Yamnaya individuals all over the northern Pontic steppes as well as in the individuals of later steppe populations connected to the "Northern Caucasian culture" and the "Catacomb culture." While the two geographical regions north and south of the Caucasus are described as showing genetically distinct populations over several millennia, there are also some signs of admixture between them, starting with the appearance of EAF in some late steppe Maikop individuals (around $3100 \mathrm{BC}$ ), and also in a substantial percentage in Yamnayarelated individuals (Wang et al. 2019). As this Anatolian Neolitic (EAF) component could have reached the Yamnaya individuals either from the south via the Caucasus or from the west via Neolithic Europe, Wang et al. (2019) perform further analyses and conclude that the Yamnaya individuals are best modelled as a mixture of EHG, ICHG, EAF, and WHG, meaning that the two latter components most likely reached the steppe via Neolithic populations from Europe, e.g., individuals connected to Globular Amphorae or Balkan Neolithic groups. They quantify this potential European Neolithic element in Yamnaya populations at around $16 \%$.

This detailed picture of Caucasian population history shows that the initial assertion in the 2015 papers, namely of a one-way migration from east to west, was a simplification supported by a variant of admixture analyses that featured Yamnaya as one unified genetic element (e.g., Haak et al. 2015, fig. 3), which led to calculations of Corded Ware individuals showing 75\% Yamnaya ancestry. This then resulted in historical scenarios of near-total extinction of the native population in central Europe (Haak et al. 2015, p. 210). There is nothing wrong, per se, with the idea to look for the least complex population model, or to try to find the admixture model with the fewest necessary source populations, but when this model is then taken to represent social processes, it is unjustified to assume that the simplest explanation best represents reality. This leads to the resurgence of block-like entities, the narrative of a single-event, unidirectional, massive migration from the steppes into central Europe.

As has been long known but recently reemphasized by Heyd (2017), the longlasting interaction between central Europe and the northern Pontic steppes (e.g., Hansen 2010; Szmyt 1999) and the Balkans (Govedarica 2004; Ivanova 2013; Kaiser and Winger 2015) is visible in the exchange of material culture items and the appearance of steppe-derived elements in the burial customs in southeast and central Europe. Recently, admixture of EAF and steppe ancestry has been found in individuals connected to fourth millennium Cucuteni-Trypillia farming communities (Immel et al. 2020), which is well compatible with the finding of genetic admixture between central Europe and the eastern European steppe region well before the third millennium BC and the fact that this admixture goes both ways.

\section{The Kristiansen Narrative}

Kristiansen et al. (2017), including several authors involved in Allentoft et al. 2015, published a refined model of a third millennium BC migration scenario. I discuss it here in some length because it is by far the best model put forward by a group of archaeologists and geneticists, but it also has problematic aspects. 
Kristiansen et al. propose a scenario of a predominantly male migration group, building on Goldberg et al. (2017) who identified a sex bias in in the admixture of steppe ancestry to the European Neolithic populations. Although this finding was challenged by Lazaridis and Reich (2017), who could not replicate the result, it is upheld by Kristiansen et al. because the archaeological record also indicates bias toward more male than female burials in Yamnaya graves as well as in early Corded Ware graves in many regions. The authors postulate an abrupt and profound change in the gene pool, and while they concede that the exact source of the incoming population is unknown, "the Yamnaya people" (Kristiansen et al. 2017, p. 335) are seen as its best proxy. Affinities between Yamnaya burials and Corded Ware burials, as well as the relative lack of archaeologically visible settlement features both in regions with Yamnaya and in some regions with Corded Ware burials, is taken as an indication that we would indeed see the move of a pastoralist society from the steppes into central Europe. The transformation from Yamnaya to Corded Ware material cultures is explained by the idea that the migrants' two main institutions-burial rituals and the organization of the household-remained intact, while pottery and material culture changed. From a number of $\mathrm{Sr}$ isotope analyses of German cemeteries of the third millennium (Sjögren et al. 2016), the contradictory pattern of more female than male mobility is resolved with a model that pictures a migration of young male pastoralist "warrior youth bands" into eastern and then central Europe, who settled down and abducted and circulated local women of Neolithic ancestry in an exogamous marriage system (Kristiansen et al. 2017, p. 339). As the women are supposed to produce the pottery, they would have been made to develop a new, Corded Ware pottery style (resembling the shape of hypothetical Yamnaya nonceramic containers).

Kristiansen has added several elements to later elaborations of this model, first, the role of the plague, as genomic evidence of yersinia pestis was identified in several late fourth millennium skeletons (Rascovan et al. 2018), combined with a drop in the summed C14-dates around $3200 \mathrm{BC}$-regarded by many archaeologists as a proxy for population numbers (see Contreras and Meadows 2014; Hinz et al. 2012; Timpson et al. 2014). Thus, Kristiansen argues that a pandemic plague event might have significantly opened up Europe for eastern migrants. A second element is the publication of the mass grave of Koszyce, southern Poland (Schroeder et al. 2019), where 15 individuals with Globular Amphora materials were violently killed and then buried according to their biological kinship relations - kin buried close to kinaround 2900 BC. Together with evidence from Eulau in central Germany, where violently killed individuals were interred in four multiple burials, this time associated with Corded Ware (Haak et al. 2008), the mass grave is taken as an indication of a significant uptick in interpersonal violence caused by the migration events. A final additional empirical argument is the finding of a reduction of diversity of male Y-chromosome haplogroups since the start of the Neolithic period, while mt haplogroups representing female lines of inheritance remain decidedly more diverse, which Zeng et al. (2018) interpret as resulting from patrilocality and competition between groups based on male lineages. This seems to fit well into Kristiansen's narrative of aggressive bands of males killing the local males and abducting their 
women. Kristiansen points to the importance of captive taking, mostly of women, in the anthropological record (Cameron 2016) and argues that it also played an important role in prehistory.

This narrative has several valuable aspects, for example, it explicitly lays out a historical scenario, clearly stated theoretical assumptions and premises, and the use of at least some anthropological models, like exogamy and captive taking. It also makes for an exciting story, which can be easily sold to the eager public (Barras 2019).

\section{A Critique of the Kristiansen Narrative}

However, the narrative developed by Kristiansen et al. also has several problematic aspects. It stands on a number of weak premises, reifying the traditional concept of archaeological cultures: "migrant Yamnaya people" and "expanding Corded Ware groups" are featured as main actors consisting of socially circumscribed groups of people, collectively migrating and fighting with "indigenous Neolithic groups" who are portrayed as largely immobile and passive. Agency is only granted to men; whenever women are found to be mobile, the interpretation is that they were abducted or handed around by men. A reversed case, like the Yamnaya Kurgan SárrétudvariOrhalom in eastern Hungary (Gerling et al. 2012), in which a burial sequence started with a local woman, followed later by interments of, among others, nonlocal men, is to my knowledge never even discussed as representing matrilocality and male exogamy (see Furholt 2019a). The main narrative is set up on the implicit premise that human history is a constant clash of (male-dominated, clearly circumscribed) cultures, in which the superior group wipes out the male part and sexually exploits the female part of the inferior population, potentially, although clearly not intentionally, evoking nefarious political connotations (Frieman and Hofmann 2019; Hakenbeck 2019; Valera and Criado Boado 2018). Kristiansen et al. (2017) is inspired by much younger accounts of how Indo-European social structures might have looked, while the archaeological arguments used to back up that view are much more ambiguous.

As discussed above, and elsewhere (Furholt 2019a), the archaeological material subsumed under the labels of Corded Ware (Furholt 2014) and Bell Beakers (see Vander Linden 2006; 2007, 2015) is by far too widespread and variable to represent unified social phenomena. Instead, very different societies used Corded Ware and Bell Beaker materials, and their formal characteristics and contexts are much more varied than suggested by the Kristiansen et al. model. Moreover, when the premise of monothetic block-like social groups is replaced with a polythetic view of the material, i.e., classifying different kinds of materials independently and allowing for overlaps between units (see Clarke 1968; Furholt 2019b), it becomes clear that the traditional culture model is inherently misleading. When it comes to burial rituals, it is not the case that there was a specific Corded Ware burial ritual as opposed to a specific Bell Beaker burial ritual. Instead, large portions of the Corded Ware material objects and the Bell Beaker material objects are connected to slight variations in a single new complex of burial rituals (Furholt 2019a). 
This new burial complex (Figs. 5 and 6) was first established in central Europe and southern Scandinavia after 2900 BC, and later in eastern Europe, the Netherlands, England, and Scotland (Furholt 2019a). It is characterized by single interments under small burial mounds, the bodies laid down in crouched positions with strict orientation rules, marked gender differentiation, a prominent role for drinking vessels (beakers and cups), and male individuals equipped with weapons. The material objects assigned to Corded Ware and Bell Beakers are not only associated with such graves but are additionally often found in regions where the new single grave burial complex did not exist, and in these regions the genetic steppe ancestry was much less present, or even largely absent (Olalde et al. 2018; see also Furholt 2019a). So, the movement of people from the east did not result in the formation of "the Corded Ware" as denoting a specific society, but it resulted in the establishment of a new set of burial rituals connected to a new set of ideological values and social roles. This new complex of burial customs and ideologies was connected to several different styles of material culture, including at first Corded Ware and later Bell Beakers, Unetice, and other Early Bronze Age units.

Several of the concrete empirical arguments that back the Kristiansen model also warrant a further discussion. The finding of yersinia pestis on Neolithic individuals is not proof of an epidemic, as nothing is known about the virulence or deadliness of the bacterium during that period. On the contrary, the fact that such bacteria have been found only in a small number of Neolithic individuals, spread out over 1500 years over the whole of Eurasia, points to low rates of transmission and mortality, at least to a scenario very different and less dramatic than the late medieval plague of the 14th century (Fuchs et al. 2019). As mentioned, the male bias in the influx of steppe ancestry (Goldberg et al. 2017) is contentious (Lazaridis and Reich 2017), and an uptick in violence during the third millennium BC cannot be inferred from two mass graves. Such finds have been made throughout prehistory (e.g., Carman and Harding 1999; Ralph 2013; Thorpe 2003), and to make inferences about trends and changing levels of violence from skeletal materials, one has to systematically collect and quantify signs of violence on human bones in the archaeological record. For modern Germany, such an endeavor has been undertaken by Peter-Röcher (2007), who collected and discussed skeletal materials with signs of injuries through the prehistoric periods. She did detect for Corded Ware burials a rate of injuries that is slightly higher than in earlier periods but clearly lower than in the Late Bronze Age or the Iron Age. Finally, the trend of a reduction Y-haplogroups (Zeng et al. 2018 ) is a worldwide phenomenon, which started around 10,000 BC, and thus cannot be taken to explain anything that would be historically specific for the third millennium BC in Europe. Nevertheless, the dominance of R1a and R1b Y-haplogroups in Europe after the third millennium BC, as opposed to a more diverse Y-haplogroup composition in the preceding period is a point worth investigating. Still, the simple picture of Yamnaya-related male lineages migrating into Europe and killing off all the native males is not consistent with the data.

While almost all male individuals from Yamnaya burials share the haplogroups R1b-Z2103 and Q1a2 (Wang et al. 2019), the great majority of all Corded Ware males share a different haplogroup, R1a (Mathieson et al. 2018). R1b, but of a different variant (P312), is the most frequent Y-chromosome haplogroup among male 
burials from Bell Beaker contexts (Olalde et al. 2018). Thus the core of the Kristiansen et al. narrative-Yamnaya males migrating into central Europe and constituting the new Corded Ware complex-is contradicted by the data. The majority of males buried in Corded Ware graves are not descendants of the Yamnaya males of which we know. The question then is from where did the R1a lineages that are the majority in Corded Ware burials come. We find R1a in Majkop graves, as well as in individuals connected to the so-called eastern European Forest Neolithic and the "Ukrainian Eneolithic" populations (Haak, personal communication 2019). This indicates that Yamnaya is not the only source of "steppe ancestry" in individuals associated with central European Corded Ware. An alternative scenario assumes that Yamnaya burials were reserved for a few selected families in the steppe, while those who migrated belonged to other, disenfranchised lineages from the same region. While such a scenario is thinkable, it is also far from an Occam's razor-like model usually preferred in the migration debates.

In addition, the fixation on Yamnaya as the source for Corded Ware formation is not a result, but rather a premise to the earlier aDNA studies that discussed third millennium migrations (Furholt 2018b, p. 168). Other eastern European source populations are possible, and the new genetic element could be connected to the Forest Neolithic or Pitted Ware complexes, all of which connected eastern and central Europe prior to and in the third millennium BC. Indeed, Corded Ware subgroups such as Fatyanovo in western Russia represent in themselves an archaeological link between central and eastern Europe (Ershova and Krenke 2013), a link for which there is as yet very little knowledge about connected biological patterns. More data for the Belorussian and western Russian Corded Ware groups should shed more light on this issue, but already now it is highly unlikely that the influx of steppe ancestry will be explained by one single process or is the result of one group of people migrating. Rather there seem to be more and different processes, and more and different groups of people involved. Whereas the new single grave burial ritual associated with Corded Ware (Furholt 2019a) started around 2900 BC, there is no temporal priority for Yamnaya kurgan graves in the Carpathian Basin over early Corded Ware (as it was long supposed). Thus, it now seems that there might be a first, pre-Yamnaya movement of people from the east into central Europe who were buried in the earliest single graves with Corded Ware. During the same time, Yamnaya graves are found in the Carpathian Basin, and at a later stage some individuals from that source mixed with the first Corded Ware generations. This second, more closely Yamanya-associated influx of people became more dominant in central European single graves only after $2500 \mathrm{BC}$, when it was predominantly connected to Bell Beaker materials.

\section{Adjusting the Premises of a Migration Narrative}

An alternative narrative is needed to scrutinize the shaky empirical evidence upon which the Kristiansen model is constructed, tone down the level of generalization it features, and deconstruct the culture-historical framework it uses. The new narrative will have to discard the criticized premises, acknowledge the variability in the 
archaeological record, and include the newest results from aDNA on the European and more-regional scales. As for the premises, instead of closed blocks of culturally uniform peoples, prehistoric communities in Neolithic Europe most probably would have been fluid and open in their social composition, where people were able to switch social groups and frequently did so, as suggested by anthropological research (Cameron 2013).

This means that instead of unified agency of archaeological cultures, individuals and small groups will have acted in different ways. Instead of assuming a single model (e.g., female exogamy) to explain the whole third millennium in central Europe, we need to take into account different kinds of local and regional movements between communities (as discussed, for example in Schachner 2012). The newest genomic data (Juras et al. 2018; Wang et al. 2019) and the archaeological record suggest that the early single graves with Corded Ware material culture are a mixture of several different source populations and migration processes in combination with active transregional networks of exchange (Bourgeois and Kroon 2017). In addition, the archaeological record suggests that the movement of people from the east into central Europe had variable effects in different regions. In most regions it did not result in the formation of "a new society" but in the emergence of a new ideological set of values that was manifested in a new burial rite that was predominantly associated with the descendants of immigrants and was integrated into different forms of social organization (Furholt 2019a). Finally, the clear unidirectionality of population movements has been called into question by Wang et al. (2019), as well as the abruptness and event-like character highlighted in the early period (Olalde et al. 2018).

\section{An Alternative Narrative of Third Millennium BC Mobility Processes}

In the late fourth and early third millennium BC, there was a drastic uptick in interregional mobility, which is archaeologically visible in the formation of extremely widespread archaeological units of classification (archaeological cultures). As discussed above, these do not represent areas of homogeneous material culture but rather different sets of similar material objects or burial rituals transregionally shared in diverse local socioeconomic and cultural contexts (see Fig. 5; Furholt 2019a). Instead of seeing these units of classification as the habitual expressions of socially homogeneous ethnic groups, as is traditionally done in the culture historical tradition, the similarities in material objects and practices over large regions are a sign of permeable community boundaries and frequent intercommunity mobility (see Furholt 2018a). Similarities in material culture between Corded Ware contexts in different regions were not restricted to the early period; instead there are several later trends that manifested themselves transregionally, like triangular vessel decorations or handled beakers (Furholt 2018a), which indicate continuous exchange and intercommunity mobility throughout the third millennium.

Also, the association of material objects and social identities is, not unexpectedly, multidimensional. For example, Bourgeois and Kroon (2017) show that similarities in burial rituals were much more uniform transregionally in male 
burials than in female ones, which indicates that specific layers of gendered identities were shared across regions, while others were not. In many contexts Corded Ware pottery was produced alongside traditional styles with not much tangible change in social practices connected to these novel vessel forms (Beckerman 2015; Iversen 2015; Kroon et al. 2019; Salzman 2010; Suter 2017). In others, their occurrence was connected to changes in the settlement pattern (Hecht 2007; Hübner 2005; Müller 1999; Schultrich 2019). The same is true for Bell Beakers (Kleijne 2019; Vander Linden 2006).

The whole setting of the third millennium BC in Europe is one that is better explained by a strengthening of translocal relations than by the traditional mass migration model. Whereas the latter has a unidirectional bias and regards human movement as a finite process - a person or group moves from A to B, the anthropological concept of translocality (Furholt 2018a; Greiner 2010; Greiner and Sakdapolrak 2013) highlights how mobile human individuals continuously engage with both the new and the old communities. They thus create links between various places and communities and develop multiple identities, which span several social places. This translocal setting continuously affects and alters all these communities and people involved: Mobility and migration break up social communities, they stir up traditional habitual practices, and they create socially even more fluid and diverse communities at the local level. They also create more thickly connected social relations between localities on the regional scale, manifest in the similarities of material objects and practices, despite diverse social organization or subsistence bases. Frachetti (2012) proposes a model of nonuniform institutional alignments, where locally diverse steppe pastoralists connected some of their social institutions through increased translocal interaction, while others remained localized.

The social institutions backing these movements most probably were variable. While the Kristiansen et al. model highlights patrilocal marriage practices, this is likely not the only way in which populations circulated (Bernardini 2011; Schachner 2012). This is visible in a number of studies that focus on local contexts. While the research project in the Lech Valley in southern Germany (Knipper et al. 2017) found more nonlocal females than males and interpreted this as female exogamy, they also registered a lack of offspring from these women in later burials. In the four multiple burials in Eulau, the authors (Haak et al. 2008) emphasize the joint burial of small groups of individuals in a manner representing core families in the modern understanding. Yet, a correspondence between social core family and the underlying idea of biological kin is present in only one of the burials, which contains a potential biological father, a potential biological mother, and two possible children. While the biological relations between the individuals in two other burials from Eulau were inconclusive, the children in the fourth were definitely not the biological offspring of the supposed mother. In both places, the Lech Valley and Eulau, including the anthropologically documented practice of exchange of children or adoption practices in the model (Silk 1980; Terrell and Modell 1994) could help better explain the evidence. The presence of nonlocal men is not explained by the female exogamy thesis, which suggests other mechanisms were at play, like households recruiting additional workforce (Angelbeck and Grier 2012; Collins 1979) or travelling craft specialists, among others. 
These studies of local communities support the idea of a generally translocal sociospatial setting not so different from the Early Neolithic, which then was caused by social fission and fusion during expansion of settlement territory. Basically, for the whole European Neolithic, intercommunity mobility was probably high. It is also important to note that the mainstream idea of long-lasting, stable settlement communities during the Neolithic in Europe is no more than an assertion, as the duration of the periods of their continuous occupation is largely unknown (Furholt 2018a). In the few cases where dendrochronology allows for precise dating-circum-alpine lake shore settlements-residence groups did not usually exist continuously for more than one or two decades (Ebersbach 2010; Ebersbach et al. 2017; Hofmann et al. 2016; Leuzinger 2002). Recently, settlement sites from the early phase of the Neolithic have produced evidence of rather short periods of occupation (Jakucs et al. 2018; Tasić et al. 2016; Whittle 2018). Together with the high degree of regional similarity of material culture, it seems justified to assume, as the baseline model for the sociospatial organization of Neolithic communities in Europe, that residential instability and a high level of social fluidity and intercommunity mobility created translocal communities (Furholt 2018a).

During the fourth and third millennia BC, there seems to have been a change, a partial widening of the networks, which shows in the archaeological record as the presence of trans-regionally shared objects and practices that superseded still existing regional differences. As the networks involving translocality widened and started to connect previously separated regions, i.e., central Europe, southeastern Europe, and the eastern European steppes, new cultural traditions and genetic lineages started showing up in regions where they had not played a major role before. Already in the later fourth millennium, transregional phenomena became increasingly visible in the archaeological record (Furholt 2008; Heyd 2017). Burial mounds first appeared in two different regions in two different manifestations. In the late fifth millennium BC, long barrows emerged in northwestern Europe (Furholt and Müller 2011; Scarre 2011), while in the early fourth millennium BC in the Caucasus region (Ivanova 2013) circular barrows, or kurgans, emerged. Both traditions later merged in Europe and combined with the originally western European megalithic tradition, which was incorporated into both long barrows and circular barrows. Since the midfourth millennium BC the use of animal traction together with the plow, wheel and wagon (Greenfield 2010; Johannsen 2006; Trifonov 2004) spread throughout central and eastern Europe as well as the Near East, largely excluding western Europe. At the same time, transregional pottery styles like Boleráz-Cernavoda III (Furholt 2008) or Kura-Arax (Chataigner and Palumbi 2014) spanned increasingly large regions, as did new burial customs, like cattle and wagon burials (Johannsen and Laursen 2010), some of them connected to Globular Amphora and Yamnaya burials (Frînculeasa et al. 2015; Kaiser and Winger 2015).

The reach and intensity of these interregional phenomena of population circulation increased during the early third millennium until the scale was so large that it crossed the boundaries of distinct ecological zones, the forested regions of temperate Europe as opposed to the steppes, within which earlier processes of population admixture after the first large population movements in the Early Neolithic had created distinct genetic population signals. As soon as the movement of 
people exceeded the boundaries of these ecological zones, this becomes visible in the aDNA record as a new quality of mixture, first, as Wang et al. (2019) have shown, from west to east, and then more massive with the main direction from east to west. Around the mid-third millennium BC this process even reached parts of western Europe and the British Isles; it then began to slow down again, and although steppe-derived ancestry reached third millennium France and Iberia, it was present in much lower percentages (Olalde et al. 2018), with a clear uptick a few centuries later (Olalde et al. 2019).

For the aDNA evidence from the third millennium BC in Europe, we also have to acknowledge a filter in our data sources: the new single burial customs under burial mounds provide the most favorable conditions for ancient DNA analyses, while other burial forms are much less accessible (Furholt 2019b). As there seems to be a connection between migrants from the east and the new single grave burial rituals, we have to assume that the contributions of other European populations is underrepresented, or at least the speed and massiveness of genetic turnover might be overestimated (see Furholt 2019a).

\section{What Caused the Two Major Upticks in Mobility?}

When we look at the overall picture of human mobility in the European Neolithic, as it has been revealed by aDNA studies in the last few years, there are two distinct periods with major changes in the European gene pool that are connected to major increases in mobility, concentrated between 6500 and $5000 \mathrm{BC}$ and between 3000 and $2000 \mathrm{BC}$. With a wider regional perspective, it is hard not to notice that these two phenomena follow after the two largest and most consequential socioeconomic transformations in western Eurasia, centered in southwest Asia, that the main direction of movement is away from the southwest Asian center, and that the communities resulting from these movements have characteristics that can be traced to these two major transformations. The first migration phenomenon is obviously connected to the Neolithic revolution, and it took place after the firm establishment of this new socioeconomic system in the mid-seventh millennium BC. After plant cultivation and animal domestication were established during the ninth millennium $\mathrm{BC}$, it was not before the end of the eighth, or the early seventh millennium that domestic animals consistently became the most important source of meat over wild animals in southwest Asia (Conolly et al. 2011), and in this phase we also see the establishment and peak of structured, concentrated villages (Banning 2012; Bartl 2012; Campbell 2012; Kuijt 2000).

The expansion of Neolithic settlers into all directions (westward from Anatolia, northward from Iran, southward from the southern Levant, see Feldman et al. 2019) seems roughly to coincide with the decline of these late Pre-Pottery Neolithic "megasites," and the social changes that led to this decline (i.e., the strengthening of household autonomy) together with external factors, like climate fluctuations, might have been the drivers of Neolithic expansion (see above). The movement of population into Europe did not start from the center of the new Neolithic world but from 
its periphery, central Anatolia. But it was closely connected to the new Neolithic economy, which migrants brought with them.

\section{The Third Millennium BC Social Transformation in Europe}

When we ask for the background of the second large population movement, in the third millennium BC, it makes sense to look, in addition to the overall timing, at the main social characteristics displayed by the newly formed communities through their material expressions during and after the period of increased mobility. The clearest manifestation of these new social characteristics in the third millennium in Europe is found in the context of burials (Fig. 6). These now newly highlight the aggrandizement of the individual (in single burials under a burial mound), the emphasis on gender (persistent marking of gender identities in the burial ritual), and the new social role of the warrior (displayed in the primary association of specialized weapons and male burials). None of these elements was totally unknown in prior periods, but the scale, prominence, and combination of elements is new. As Robb and Harris (2018) recently argued, gender was a relevant social factor in Neolithic societies, but it seems to have been much less salient and prominent (e.g., in the burial ritual) a factor as compared to the period after 3000 BC. Individual aggrandizement, in the form of large monumental burial mounds for single individuals, was already present in the early megalithic traditions of northwestern Europe (fifth millennium, Scarre 2011), and in Maikop burials of the fourth millennium (Ivanova 2013), but these are much less numerous than third millennium burial mounds.

While violent raids and massacres of whole communities have been documented in the Neolithic, e.g., in Talheim (Wahl and Trautmann 2012), Schletz (TeschlerNicola 2012), and Schöneck-Kilianstedten (Meyer et al. 2015), they were carried out with tools like axes, or bows and arrows, that were usually used for nonviolent purposes, like woodwork or hunting. During the Neolithic, tools were not frequently made as specialized weapons for interpersonal violence; exceptions, perhaps, are maceheads and some more elaborate forms of shaft-hole axes (e.g., Chapman 1999). Also, there are very few archaeological signs of the existence of specialized fighters or warriors (Schulting 2013). Potential specialized weapons in male burials began to appear more frequently in the form of shaft-hole axes only in the fifth millennium, after $4750 \mathrm{BC}$ during the Late Neolithic in some regions of southeast Europe (Osztás et al. 2016; Zalai-Gaál et al. 2012), most notably in the form of copper axes during the middle of the fifth millennium during Copper Age in the Carpathian Basin and the Balkans (Bognár-Kutzián 1963; Krauß et al. 2017). However, the popularity of such copper shaft-hole axes ceased after the fifth millennium, and it was only by the second half of the fourth millennium BC that specialized weapons in the form of battle axes, daggers, and halberds (i.e., daggers shafted like axes, see Dolfini et al. 2018; Horn 2018) became more frequent. They proliferated with the start of Corded Ware and Bell Beakers, where they are associated with male burials, an association that has remained in place in this part of the world ever since. In sum, what is highlighted in the new single grave burials, the Yamnaya burials, and the early Corded Ware and Bell Beaker burials is the aggrandized individual, a new importance of 
gender differences, including a stronger emphasis on the display of male gender identity (Bourgeois and Kroon 2017), connected to the display of male individuals as perpetrators of violence.

\section{Early Urbanization as a Context to Social Processes in Europe}

The second major population turnover in Europe is contemporary with the urban revolution and coincided with the establishment of early city states in southwest Asia. In Mesopotamia, scholars believe social stratification started in the Ubaid period, in the fifth millennium BC, while real urbanism and centralized leadership developed during the fourth millennium BC Uruk period in southern Mesopotamia and, probably independent from that, in the Late Chalkolithic (LC) 2 and 3 periods in northern Mesopotamia (Algaze 2009; McMahon 2019; Oates et al. 2007; Stein 2012; Ur et al. 2007). Early states are characterized — among many other things—by institutionalized social stratification, which was established and upheld by coercive force. Such a system would have been experienced as quite a contrast to the sociopolitical modes of organization known in the great majority of Neolithic communities in Europe. Although far from being peaceful in general (see Kelly 2000; Thorpe 2003), due to the lack of specialized weapons (Chapman 1999), specialized fighters, and the absence of larger degrees of political centralization (Furholt et al. 2020), most Neolithic communities lacked the means to create a significant imbalance in the possibility to muster violent coercion. Thus attempts to create a regime of coercive domination over others would most likely have been met with the mobilization of counter-power from people who were just as capable of assembling a group of people wielding their wood-working or hunting tools for protection or resistance. This changed as soon as specialists trained in the use of the newly developed weapons appeared (Schulting 2013). A group of such warriors probably would have been able to terrorize others into obedience.

For the Neolithic we have to think of other practices of conflict resolution than those familiar to us from state societies. Anthropological studies of societies without centralized governments (Amborn 2019) demonstrate that power could to a much higher degree have been based on negotiation, persuasion, or authority rather than on coercion, which was available only to a limited degree. With the emergence of early states, the specialized warrior emerged as the central means for and symbol of power, which was then to a much larger degree based on coercion. It can thus be argued that both the notion of individual aggrandizement and specialized warriorhood are concepts that, although not unknown before, gained a significantly higher importance during the process of early state formation. Both are connected to the establishment of a durable system of social stratification, which also likely involved a change in gender relations. Lerner (1987) has argued that patriarchy emerged in Mesopotamian urban environments in a process in which female subordination to male dominance was built on the commodification of women's sexuality and reproductive capacities, a process strongly connected to the creation of private property and the monetization of social relations (see also Graeber 2014, pp. 182-184). Patriarchy, the strict control of women's sexuality by their families, both Lerner and 
Graeber argue, could be understood as a reaction of peripheral herder communities who were in contact with the urban centers to the real and often experienced threat to their family members of slavery and prostitution.

Early urbanism and state formation was a social transformation probably even more consequential than the Neolithic revolution, and it features the three main components that were brought to central and western Europe in the course of the third millennium migration processes: individual aggrandizement, institutionalized warriorhood, and marked gender roles with an advantage for males.

This is not to evoke a simple core-periphery or ex oriente lux model. The three new social elements pointed out here were not invented in Mesopotamia and then spread out from there. Instead, all three can be traced back individually to different parts of Eurasia; they probably emerged in the context of long-lasting processes, only culminating in Mesopotamia and Egypt at the turn from the fourth to the third millennium BC. First archaeological manifestations of specialized weapons, gender differences, and individual aggrandizement in burials are, as mentioned above, spatially and temporally isolated, such as in the southeastern European Copper Age, e.g., in Varna in the mid-fifth millennium BC, which already can be seen in the context of incipient urbanization processes in southwest Asia (Ivanova 2013). In contrast, the fifth millennium BC megaliths and long barrows in northwestern Europe are likely unrelated to western Asian urbanization. Then again, Maikop burial mounds of the Caucasus region, some of which contain rich metal equipment, are a phenomenon that is quite likely connected to these developments that took place not far to the south (Ivanova 2013). During the Majkop period, possibly even slightly earlier (Kohl 2007, p. 75), the social innovation of the burial mound was likely connected to the fundamental transformations taking place in Mesopotamia at that time. The kurgan, together with an ideological package, aggrandizing certain individuals, emphasizing gender, showing gender inequality by favoring males, displaying the male warrior, probably formed in this Majkop context and was from there brought farther to the north and west.

Like in the Early Neolithic, the uptick in mobility that ultimately reached Europe began in a region close but peripheral to one of the centers of change, likely the Caucasus and steppes and areas to the north. The expansion of southern Mesopotamian Uruk communities through trade and colonization dates to around 3700 to 3100 BC (Algaze 1993). Similar developments were likely occurring in northern Mesopotamia at the same time (McMahon 2019). This period is one of profound change not only in Mesopotamia but also Europe. The mid-fourth millennium has been identified as a period of heavily accelerated innovation in the realm of technology and social organization (Hansen 2010). At that time, the plow, wheel, and wagon, combined with animal traction, first appeared in Europe and then rapidly spread across the continent (Bakker et al. 1999; Sherratt 1981). The idea that these developments might be connected is old but nevertheless compelling.

The emerging state systems in Mesopotamia probably created a vast and unprecedented demand on raw materials, resources, goods, and human labor (e.g., Anthony 2007) that most likely affected not only the direct vicinity but also communities in neighboring ecological zones. Such a demand could have facilitated the creation of Kura-Arax and Maikop-related societies in the Caucasus area (Fig. 7), which seem 
to have had access to metals. Although pastoralism is a much older phenomenon (Makarewicz 2013), the vast demand for animal products could have supported the forming, or at least the intensification, of pastoralist ways of life in the European steppe zones (see Frachetti 2012). And it could have also affected hunter-fisher-gatherers of the forest zone, who could have delivered furs, wood, and other resources.

Direct archaeological signs for contacts between southwest Asia, the northern Pontic regions, and regions farther north in the fourth and early third millennia BC are relatively scarce, but there are finds of glass pearls of southwest Asian origin in the cemetery of Usatovo (Anthony 2007, pp. 354-355). Indirect links between the steppes and Mesopotamia are more numerous. While the Kura-Arax complex bridged northern Mesopotamia and the Caucasus region, Maikop material culture and the new custom of burial mounds linked the areas south and north of the Caucasus (see Fig. 7; Ivanova 2013; Kohl 2007, p. 75). Kurgans subsequently spread into the northern steppes and beyond (Anthony 2007; Kaiser 2019). The new wheel and wagon technology most likely also spread along this route (Bakker et al. 1999; Maran 2004).

The interconnection between early city states and surrounding mobile pastoralists is an old trope in Near Eastern studies (the so-called "dependency theory," see Anthony 2007), but this does not per se disqualify the argument. Rather, we have to understand if and how such an interconnection could have had such far-reaching consequences that it could transform the whole area of eastern and later central and even western Europe.

The establishment of early state societies was most probably a violent and traumatic process to the great majority of people living in and close to those regions. The new importance of specialized warriors enabled increasingly powerful individuals or groups to establish a rule of the fist instead of what had until then mostly been social interactions structured around kinship relations, social ties, and interaction among peers or groups of peers. Hamblin (2006, p. 21) argues that the "Uruk expansion" (Algaze 1993) connected to early state formation in Mesopotamia was a process of coercive imperialism, the crossing of the "military threshold", which refers to the point after which warfare "... becomes endemic in a region, and at which all peoples in a region are forced to militarize their societies" (Hamblin 2006, p. 16), visible in "...monumental building leading to fortifications, the development of ideological art, much of it with military themes, and the rise of social stratification with domination by martial kings and elites" (Hamblin 2006, pp. 35-36).

For societies unfamiliar to this level of unchecked top-down rule by coercion, the social disruption such developments must have caused cannot be underestimated. In the face of blatant and impersonal violence, a better option than open rebellion was to leave, as was practiced for a long time (e.g., Furholt et al. 2020). In southwest Asia, the biblical record prominently features the phenomenon of "exodus," from early states to peripheral herding communities (Diákonov 1982), albeit in a later period. But there are no grounds to believe that the same kind of movement did not already exist with the formation of state powers in the fourth millennium BC. On the one hand, the more powerful and wealthy urban centers and early states became, the more people were attracted to them. On the other hand, and most crucially for the argument developed here, more people also were likely to have to or want to flee 
from violence, oppression, and humiliation executed by these early state institutions. This can very well have led to a chain-reaction, a general stirring up of previously less mobile communities, leading to the rising level of mobility, which facilitated the transregional spread of technological innovations in the late fourth millennium but also the increased intercommunity mobility we see especially in the third millennium in Europe.

However, as was the case in the Early Neolithic, the ideological package that came with the migrants was a watered-down version of the original. While the largest individual monuments are known from the Maikop phase (Belinskij et al. 2016; Korenevskij 2010) in the fourth millennium BC, third millennium BC Yamnaya and Corded Ware kurgans are decidedly more modest in size (Bourgeois 2013). Instead of outstandingly large or elaborate kurgans as known from the Maikop context, we see over time a proliferation of these kinds of burials, toward a pattern of large numbers of small and simple burial mounds. Proliferation is a well-known pattern of bottom-up resistance against a mechanism that supports social stratification (Angelbeck and Grier 2012). An effective instrument of domination or an effective tool for status building can be undermined by expanding access to it, thus diminishing its effectiveness. This could be an unintended process, driven just out of the desire of an increasing number of individuals to be part of this exclusive new elite group, but it could also very well have been consciously done. In any event, it allows for certain symbols of wealth and power to be integrated in a less stratified society without totally having to reject the attractive new items or new social roles.

If the state formation processes of the fourth and third millennium in Mesopotamia are seen as the main driving force for the large-scale mobility uptick of the third millennium BC, the results were multiple and variable. The effects of both the centripetal (demand for resources) and the centrifugal (exodus from coercive centers) forces would have affected all kinds of different communities close by and farther away. The new ideological and social values and institutions that spread out of southwest Asia would have created crises in old belief systems and social orders, as would the technological innovations being spread around the area. All these factors would create a self-reinforcing mobilization and transformation of societies, creating first the heterogeneous expressions of Yamnaya burial customs, and later the likewise heterogeneous versions of single grave burials connected with Corded Ware and Bell Beaker materials, which were integrated into or put beside the diverse social groups in central and western Europe.

\section{Conclusion}

In the last decade, roughly, two major population turnovers were identified by ancient DNA studies: the "Early Neolithic" (6600-5000 BC) and the "Late Neolithic" or "Early Bronze Age' (3000-2000 BC). This had an enormous effect on our view of prehistory and, especially, our views on the importance of human mobility in social change. However, the narratives connected to these turnovers show a stark imbalance between the sophistication of biological work and archaeological contextualization. Initially overwhelmed by the analytical and computational power 
of aDNA studies, by the impact of the natural scientific publication system, archaeologists failed to contribute to an interdisciplinary discourse with the theoretical sophistication and empirical base of knowledge available. Instead, the aDNA data were included in overgeneralizing, simplistic narratives, heavily biased by longoutdated 20th century culture-historical views of collectively migrating, biologically homogeneous social groups with too little regard for anthropological or archaeological theory or the current knowledge of the archaeological record. The main flaw of the narratives spun around both periods - the Early Neolithic and the Early Bronze Age - is the idea of monothetic archaeological cultures or, at a deeper level, the mindset behind such a kind of concept, the idea of the existence of clearly bounded, internally homogeneous groups of people, the essentializing of ethnic identities. Add to this a good portion of western stereotypes about gender roles and the nature of human agency, and the results are the kind of narratives put forward about the newly discovered migrations in prehistory.

If we pick apart those biases and prejudices, the scenarios for human movement during the Early Neolithic and the Early Bronze Age will be more complicated and regionally diverse. The alternative narratives proposed here are less concrete and less easy to communicate because they allow for and acknowledge regionally and locally specific histories, modifications of overall influences and trends that are clearly indicated by the diversity of the archaeological record. It is still possible, however, to reasonably discuss main drivers or even prime movers of these transcontinental clusters of connected movements, in both timeframes deriving from southwest Asia, where two of the most consequential transformations of social and economic systems during human history took place. The first brought agriculture, animal husbandry, and sedentary village life, the second is connected to a new ideological system that to a higher degree than before featured violent coercion, more fixed and unequal gender relations, and individual aggrandizement that took hold in European communities, changes that later became more important in Bronze Age and Iron Age societies.

Open Access This article is licensed under a Creative Commons Attribution 4.0 International License, which permits use, sharing, adaptation, distribution and reproduction in any medium or format, as long as you give appropriate credit to the original author(s) and the source, provide a link to the Creative Commons licence, and indicate if changes were made. The images or other third party material in this article are included in the article's Creative Commons licence, unless indicated otherwise in a credit line to the material. If material is not included in the article's Creative Commons licence and your intended use is not permitted by statutory regulation or exceeds the permitted use, you will need to obtain permission directly from the copyright holder. To view a copy of this licence, visit http://creativecommons.org/licen ses/by/4.0/.

\section{References Cited}

Ahola, M., and Heyd, V. (2020). The northern way: Graves and funerary practices in Corded Ware Finland. Praehistorische Zeitschrift 95: 15-27.

Algaze, G. (1993). The Uruk World System: The Dynamics of Expansion of Early Mesopotamian Civilization, 2nd ed., University of Chicago Press, Chicago. 
Algaze, G. (2009). Ancient Mesopotamia at the Dawn of Civilization: The Evolution of an Urban Landscape, University of Chicago Press, Chicago.

Allentoft, M. E., Sikora, M., Sjogren, K.-G., Rasmussen, S., Rasmussen, M., Stenderup, J., et al. (2015). Population genomics of Bronze Age Eurasia. Nature 522: 167-172.

Amborn, H. (2019). Law as Refuge of Anarchy: Societies without Hegemony or State, MIT Press, Cambridge, MA.

Ammerman, A. J., and Cavalli-Sforza, L. L. (1971). Measuring the rate of spread of early farming in Europe. Man 6: 674-688.

Ammerman, A. J., and Cavalli-Sforza, L. L. (1984). The Neolithic Transition and the Genetics of Populations in Europe, Princeton University Press, Princeton, NJ.

Angelbeck, B., and Grier, C. (2012). Anarchism and the archaeology of anarchic societies: Resistance to centralization in the Coast Salish region of the Pacific Northwest coast. Current Anthropology 53: $547-587$.

Anthony, D. W. (1990). Migration in archaeology: The baby and the bathwater. American Anthropologist 92: 895-914.

Anthony, D. W. (2007). The Horse, the Wheel, and Language: How Bronze-Age Riders from the Eurasian Steppes Shaped the Modern World, Princeton University Press, Princeton, NJ.

Bakker, J. A., Kruk, J., Lanting, A. E., and Milisauskas, S. (1999). The earliest evidence of wheeled vehicles in Europe and the Near East. Antiquity 73: 778-790.

Bánffy, E. (2004). Advances in the research of the Neolithic transition in the Carpathian Basin. In Lukes, A., and Zvelebil, M. (eds.), LBK Dialogues: Studies in the Formation of the Linear Pottery Culture, BAR International Series No. 1304, Archaeopress, Oxford, pp. 49-70.

Bánffy, E. (2019). First Farmers of the Carpathian Basin: Changing Patterns in Subsistence, Ritual and Monumental Figurines, Oxbow Books, Philadelphia, PA.

Bánffy, E., and Oross, K. (2010a). The earliest and earlier phase of the LBK in Transdanubia. Die Neolithisierung Mitteleuropas 4: 255-272.

Bánffy, E., and Oross, K. (2010b). The earliest and earlier phase of the LBK in Transdanubia. In Gronenborn, D., and Petrasch, J. (eds.), Die Neolithisierung Mitteleuropas: The Spread of the Neolithic to Central Europe: International Symposium, Mainz 24 June-26 June 2005, RGZM, Mainz, pp. $255-272$.

Banning, E. B. (2012). The southern Levant. In Potts, D. T. (ed.), A Companion to the Archaeology of the Ancient Near East, Blackwell, Oxford, pp. 396-414.

Barras, C. (2019). Story of most murderous people of all time revealed in ancient DNA. New Scientist 3223: 29-33.

Barth, F. (ed.) (1969). Ethnic Groups and Boundaries: The Social Organization of Culture Difference, Universitetsforlaget, Oslo.

Bartl, K. (2012). The northern Levant. In Potts, D. T. (ed.), A Companion to the Archaeology of the Ancient Near East, Blackwell, Oxford, pp. 375-395.

Beau, A., Rivollat, M., Réveillas, H., Pemonge, M.-H., Mendisco, F., Thomas, Y., Lefranc, P., and Deguilloux, M.-F. (2017). Multi-scale ancient DNA analyses confirm the western origin of Michelsberg farmers and document probable practices of human sacrifice. PLOS ONE 12: e0179742.

Beckerman, S. M. (2015). Corded Ware Coastal Communities: Using Ceramic Analysis to Reconstruct Third Millennium BC Societies in the Netherlands, Sidestone Press, Leiden.

Behre, K.-E. (2007). Evidence for Mesolithic agriculture in and around central Europe? Vegetation History and Archaeobotany 16: 203-219.

Belinskij, A. B., Hansen, S. and Reinhold, S. (2016). The Great Kurgan from Nalčik: A preliminary report. In Rova, E., and Tonussi, M. (eds.), At the Northern Frontier of Near Eastern Archaeology: Recent Research on Caucasia and Anatolia in the Bronze Age. Proceedings of the International Humboldt-Kolleg Venice, January 9th-January 12th, 2013, Brepols, Turnhout, pp. 13-32.

Bentley, R. A., Bickle, P., Fibiger, L., Nowell, G. M., Dale, C. W., Hedges, R. E. M., et al. (2012). Community differentiation and kinship among Europe's first farmers. Proceedings of the National Academy of Sciences 109: 9326-9330.

Bentley, R. A., Price, T. D., Lüning, J., Gronenborn, D., Wahl, J., and Fullagar, P. D. (2002). Prehistoric migration in Europe: Strontium isotope analysis of Early Neolithic skeletons. Current Anthropology 43: 799-804.

Bentley, R. A., Wahl, J., Price, T. D., and Atkinson, T. C. (2008). Isotopic signatures and hereditary traits: Snapshot of a Neolithic community in Germany. Antiquity 82: 290-304. 
Bergsvik, K. A. (2012). The last hunter-fishers of western Norway. In Prescott, C., and Glørstad, H. (eds.), Becoming European: The Transformation of Third Millennium Northern and Western Europe, Oxbow Books, Oxford, pp. 100-114.

Bernabeu Aubán, J., Hernández, F. J. M., Köhler, T. O., Castillo, A. D., and Puche, M. G. (2003). Mas d'Is (Penàguila, Alicante): Aldeas y recintos monumentales del Neolítico Inicial en el valle del Serpis. Trabajos de Prehistoria 60: 39-59.

Bernardini, W. R. (2011). Migration in fluid social landscapes. In Cabana, G. S., and Clark, J. J. (eds.), Rethinking Anthropological Perspectives on Migration, University Press of Florida, Gainesville, pp. 31-44.

Besse, M. (2003). Les céramiques communes des campaniformes européens. Gallia Préhistoire 45: $205-258$.

Besse, M. (2004). Bell Beaker common ware during the third millennium BC in Europe. In Czebreszuk, J. (ed.), Similar but Different: Bell Beakers in Europe, Adam Mickiewicz University, Poznán, pp. $127-148$.

Biagi, P., Shennan, S., and Spataro, M. (2005). Rapid rivers and slow seas? New data for the radiocarbon chronology of the Balkan Peninsula. In Nikolova, L., Fritz, J., and Higgins, J. (eds.), Prehistoric Archaeology and Anthropological Theory and Education, Karlovo, Salt Lake City, UT, pp. 41-50.

Bickle, P., and Whittle, A. (eds.) (2013). The First Farmers of Central Europe: Diversity in LBK Lifeways, Oxbow Books, Oxford.

Biehl, P. F., Gramsch, A., and Marciniak, A. (eds.) (2002). Archäologien Europas: Geschichte, Methoden und Theorien, Waxmann, Münster.

Bocquet-Appel, J. P., and Bar-Yosef, O. (eds.) (2008a). Demography and Storage Systems During the Southern Levantine Neolithic Demographic Transition, Springer, New York.

Bocquet-Appel, J.-P., and Bar-Yosef, O. (eds.) (2008b). The Neolithic Demographic Transition and Its Consequences, Springer, Dordrecht.

Bocquet-Appel, J.-P., Naji, S., Vander Linden, M., and Kozlowski, J. (2012). Understanding the rates of expansion of the farming system in Europe. Journal of Archaeological Science 39: 531-546.

Bognár-Kutzián, I. (1963). The Copper Age Cemetery of Tiszapolgár-Basatanya, Akadémiai Kiadó, Budapest.

Bollongino, R., Nehlich, O., Richards, M. P., Orschiedt, J., Thomas, M. G., Sell, C., Fajkošová, Z., Powell, A., and Burger, J. (2013). 2000 years of parallel societies in Stone Age central Europe. Science 342: 479-481.

Borić, D. (2016). Deathways at Lepenski Vir: Patterns in Mortuary Practice, Serbian Archaeological Society, Belgrade.

Borić, D., Borovinić, N., Đuričić, L., Bulatović, J., Gerometta, K., Filipović, D., Allué, E., VušovićLučić, Z., and Cristiani, E. (2019). Spearheading into the Neolithic: Last foragers and first farmers in the Dinaric Alps of Montenegro. European Journal of Archaeology 22: 470-488.

Borić, D., and Price, T. D. (2013). Strontium isotopes document greater human mobility at the start of the Balkan Neolithic. Proceedings of the National Academy of Sciences 110: 3298-3303.

Borić, D., and Schulting, R. (2017). A tale of two processes of Neolithisation: South-east Europe and Britain/Ireland. In Bickle, P., Cummings, V., Hofmann, D., and Pollard, J. (eds.), The Neolithic of Europe: Papers in Honour of Alasdair Whittle, Oxbow, Oxford, pp. 82-106.

Bourgeois, Q. (2013). Monuments on the Horizon: The Formation of the Barrow Landscape Throughout the 3rd and 2nd Millennium BC, Sidestone Press, Leiden.

Bourgeois, Q., and Kroon, E. (2017). The impact of male burials on the construction of Corded Ware identity: Reconstructing networks of information in the 3rd millennium BC. PLOS ONE 12: e0185971.

Brace, S., Diekmann, Y., Booth, T. J., van Dorp, L., Faltyskova, Z., Rohland, N., et al. (2019). Ancient genomes indicate population replacement in Early Neolithic Britain. Nature Ecology \& Evolution 3: 765-771.

Bradley, R. (2007). The Prehistory of Britain and Ireland, Cambridge University Press, Cambridge.

Bramanti, B., Thomas, M. G., Haak, W., Unterländer, M., Jores, P., Tambets, K., et al. (2009). Genetic discontinuity between local hunter-gatherers and central Europe's first farmers. Science 326: 137-140.

Brami, M. N. (2017). The Diffusion of Neolithic Practices from Anatolia to Europe: A Contextual Study of Residential Construction, 8500-5500 BC cal., BAR International Series No. 2838, Archaeopress, Oxford. 
Brami, M., and Zanotti, A. (2015). Modelling the initial expansion of the Neolithic out of Anatolia. Documenta Praehistorica 42: 103-116.

Brandt, G., Haak, W., Adler, C. J., Roth, C., Szécsényi-Nagy, A., Karimnia, S., et al. (2013). Ancient DNA reveals key stages in the formation of central European mitochondrial genetic diversity. Science 342: 257-261.

Brandt, G., Knipper, C., Nicklisch, N., Ganslmeier, R., Klamm, M., and Alt, K. W. (2014). Settlement burials at the Karsdorf LBK site, Saxony-Anhalt, Germany: Biological ties and residential mobility. In Whittle, A., and Bickle, P. (eds.), Early Farmers: The View from Archaeology and Science, Oxford University Press, Oxford, pp. 95-114.

Broushaki, F., Thomas, M. G., Link, V., López, S., van Dorp, L., Kirsanow, K., et al. (2016). Early Neolithic genomes from the eastern Fertile Crescent. Science 353: 499-503.

Burmeister, S. (2000). Archaeology and migration. Approaches to an archaeological proof of migration. Current Anthropology 41: 539-567.

Cameron, C. M. (2013). How people moved among ancient societies: Broadening the view. American Anthropologist 115: 218-231.

Cameron, C. M. (2016). Captives: How Stolen People Changed the World, University of Nebraska Press, Lincoln.

Campbell, S. (2012). Northern Mesopotamia. In Potts, D. T. (ed.), A Companion to the Archaeology of the Ancient Near East, Blackwell, Oxford, pp. 415-430.

Chapman, J. (1999). The origins of warfare in the prehistory of central and eastern Europe. In Carman, J., and Harding, A. (eds.), Ancient Warfare, Sutton, Stroud, pp. 101-42.

Carman, J., and Harding, A. (eds.) (1999). Ancient Warfare, Sutton, Stroud.

Chataigner, C., and Palumbi, G. (eds.) (2014). The Kura-Araxes culture from the Caucasus to Iran, Anatolia and the Levant: Between unity and diversity. Paléorient 40: 1-216.

Childe, V. G. (1925). The Dawn of European Civilization, K. Paul, Trench, Trubner and Co., London.

Childe, V. G. (1929). The Danube in Prehistory, Oxford University Press, London.

Childe, V. G. (1933). Is prehistory practical? Antiquity 7: 410-418.

Çilingiroğlu, Ç. (2005). The concept of "Neolithic package": Considering its meaning and applicability. Documenta Praehistorica XXXII, Neolithic Studies 12: 1-13.

Çilingiroğlu, Ç. (2012). The Neolithic Pottery of Ulucak in Aegean Turkey: Organization of Production, Interregional Comparisons and Relative Chronology, BAR International Series No. 2426, Archaeopress, Oxford.

Çilingiroğlu, Ç. (2016). Impressed pottery as a proxy for connectivity in the Neolithic Aegean and eastern Mediterranean. In Molloy, B. (ed.), Of Odysseys and Oddities: Scales and Modes of Interaction Between Aegean Societies and Their Neighbours, Sheffield Studies in Aegean Archaeology, Oxbow Books, Oxford, pp. 75-96.

Clarke, D. L. (1968). Analytical Archaeology, Methuen, London.

Clarke, D. L. (1970). Beaker Pottery of Great Britain and Ireland, Cambridge University Press, Cambridge.

Collins, J. M. (1979). Multilineal descent: A Coast Salish strategy. In Hinshaw, R. (ed.), Currents in Anthropology: Essays in Honour of Sol Tax, Mouton, New York, pp. 243-254.

Conolly, J., Colledge, S., Dobney, K., Vigne, J. D., Peters, J., Stopp, B., Manning, K., and Shennan, S. (2011). Meta-analysis of zooarchaeological data from SW Asia and SE Europe provides insight into the origins and spread of animal husbandry. Journal of Archaeological Science 38: 538-545.

Contreras, D. A., and Meadows, J. (2014). Summed radiocarbon calibrations as a population proxy: A critical evaluation using a realistic simulation approach. Journal of Archaeological Science 52: 591-608.

Cook, T. G., Bonsall, C., Hedges, R. E. M., McSweeney, K., Boroneanţ, V., Bartosiewicz, L., and Pettitt, P. B. (2002). Problems of dating human bones from the Iron Gates. Antiquity 76: 77-85.

Coward, F., Shennan, S. J., Colledge, S., Conolly, J., and Collard, M. (2008). The spread of Neolithic plant economies from the Near East to northwest Europe: A phylogenetic analysis. Journal of Archaeological Science 35: 42-56.

Cummings, V., and Harris, O. (2011). Animals, people and places: The continuity of hunting and gathering practices across the Mesolithic-Neolithic transition in Britain. European Journal of Archaeology 14: 361-393.

Czebreszuk, J. (ed.) (2014). Similar but Different: Bell Beakers in Europe, 2nd ed., Sidestone Press, Leiden. 
Damm, C. (1991). The Danish single grave culture-Ethnic migration or social construction? Journal of Danish Archaeology 10: 199-204.

Demoule, J.-P. (2014). Mais où sont passés les Indo-Européens? Le mythe d'origine de l'Occident, Le Seuil, Paris.

Demoule, J.-P., and Perlès, C. (1993). The Greek Neolithic: A new review. Journal of World Prehistory 7: 355-416.

Denaire, A., Lefranc, P., Wahl, J., Bronk Ramsey, C., Dunbar, E., Goslar, T., Bayliss, A., Beavan, N., Bickle, P., and Whittle, A. (2017). The cultural project: Formal chronological modelling of the Early and Middle Neolithic sequence in Lower Alsace. Journal of Archaeological Method and Theory 24: 1072-1149.

Diákonov, I. M. (1982). The structure of the Near Eastern society before the middle of the 2nd millennium BC. Oikumene 3: 7-100.

Dolfini, A., Crellin, R. J., Horn, C., and Uckelmann, M. (2018). Interdisciplinary approaches to prehistoric warfare and violence: Past, present, and future. In Dolfini, A., Crellin, R. J., Horn, C., and Uckelmann, M. (eds.), Prehistoric Warfare and Violence: Quantitative and Qualitative Approaches, Springer, Cham, pp. 1-18.

Domboróczki, L., and Raczky, P. (2010). Excavations at Ibrány and the northernmost distribution of the Körös culture. In Kozlowski, J. K., and Raczky, P. (eds.), Neolithization of the Carpathian Basin: Northernmost Distribution of the Starčevo/Körös Culture: Papers on the Symposium Organized by the EU Projekt FEPRE., Polska Akademia Umiejętności, Krakow, pp. 191-218.

Düring, B. S. (2011). The Prehistory of Asia Minor: From Complex Hunter-Gatherers to Early Urban Societies, Cambridge University Press, New York.

Düring, B. S. (2013). Breaking the bond: Investigating the Neolithic expansion in Asia Minor in the seventh millennium BC. Journal of World Prehistory 26: 75-100.

Ebersbach, R. (2010). Seeufersiedlungen und Architektursoziologie-Ein Anwendungsversuch. In Trebsche, P., Müller-Scheeßel, N., and Reinhold, S. (eds.), Der Gebaute Raum - Bausteine Einer Architektursoziologie Vormoderner Gesellschaften, Waxmann, Münster, pp. 193-212.

Ebersbach, R., Doppler, T., Hofmann, D., and Whittle, A. (2017). No time out: Scaling material diversity and change in the alpine foreland Neolithic. Journal of Anthropological Archaeology 45: 1-14.

Eggert, M. K. H. (1978). Zum Kulturkonzept in der Prähistorischen Archäologie. Bonner Jahrbücher 178: $1-20$.

Eisenmann, S., Bánffy, E., van Dommelen, P., Hofmann, K. P., Maran, J., Lazaridis, I., et al. (2018). Reconciling material cultures in archaeology with genetic data: The nomenclature of clusters emerging from archaeogenomic analysis. Scientific Reports 8: 13003.

Erny-Rodmann, C., Gross-Klee, E., Haas, J.-N., Jacomet, S., and Zoller, H. (1997). Früher "human impact" und Ackerbau im Übergangsbereich Spätmesolithikum-Früneolithikum im schweizerischen Mittelland. Jahrbuch der Schweizerischen Gesellschaft für Ur- und Frühgeschichte. 80: 27-56.

Ershova, E., and Krenke, N. (2013). Corded Ware, Fatyanovo and Abashevo culture sites on the floodplain of the Moskva River. Sprawozdania Archeologiczne 65: 415-426.

Feldman, M., Fernández-Domínguez, E., Reynolds, L., Baird, D., Pearson, J., Hershkovitz, I., et al. (2019). Late Pleistocene human genome suggests a local origin for the first farmers of central Anatolia. Nature Communications 10: 1218.

Fischer, A. (2002). Food for feasting? An evaluation of explanations of the Neolithisation of Denmark and southern Sweden. In Fischer, A., and Kristiansen, K. (eds.), The Neolithisation of Denmark: 150 Years of Debate, J. R. Collis, Sheffield, pp. 341-393.

Fokkens, H., and Nicolis, F. (eds.) (2012). Background to Beakers: Inquiries into Regional Cultural Backgrounds of the Bell Beaker Complex, Sidestone Press, Leiden.

Frachetti, M. D. (2012). Multiregional emergence of mobile pastoralism and nonuniform institutional complexity across Eurasia. Current Anthropology 53: 2-38.

Frieman, C. J., and Hofmann, D. (2019). Present pasts in the archaeology of genetics, identity, and migration in Europe: A critical essay. World Archaeology 51: 528-545.

Frînculeasa, A., Preda, B., and Heyd, V. (2015). Pit-graves, Yamnaya and Kurgans along the Lower Danube: Disentangling IVth and IIIrd millennium BC burial customs, equipment and chronology. Praehistorische Zeitschrift 90: 45-113.

Fuchs, K., Rinne, C., Drummer, C., Immel, A., Krause-Kyora, B., and Nebel, A. (2019). Infectious diseases and Neolithic transformations: Evaluating biological and archaeological proxies in the German loess zone between 5500 and 2500 BCE. The Holocene 29: 0959683619857230. 
Furholt, M. (2003). Die absolutchronologische Datierung der Schnurkeramik in Mitteleuropa und Südskandinavien, Habelt, Bonn.

Furholt, M. (2008). Pottery, cultures, people? The European Baden material re-examined. Antiquity 82: $617-628$.

Furholt, M. (2009). Die nördlichen Badener Keramikstile im Kontext des mitteleuropäischen Spätneolithikums (3650-2900 v. Chr.), Dr. Rudolf Habelt GmbH, Bonn.

Furholt, M. (2014). Upending a "totality": Re-evaluating Corded Ware variability in Late Neolithic Europe. Proceedings of the Prehistoric Society 80: 67-86.

Furholt, M. (2016). Settlement layout and social organisation in the earliest European Neolithic. Antiquity 90: $1196-1212$.

Furholt, M. (2017a). Das ägäische Neolithikum und Chalkolithikum-Transformationen sozialer Handlungmuster in Anatolien und Griechenland zwischen 6500 und 4000 v. Chr., Habelt, Bonn.

Furholt, M. (2017b). Socio-spatial organisation and Early Neolithic expansion in western Anatolia and Greece. In Gori, M., and Ivanova, M., (eds.), Balkan Dialogues: Negotiating Identity between Prehistory and the Present, Routledge, Oxford, pp. 111-130.

Furholt, M. (2018a). Translocal communities-Exploring mobility and migration in sedentary societies of the European Neolithic and Early Bronze Age. Praehistorische Zeitschrift 92: 304-321.

Furholt, M. (2018b). Massive migrations? The impact of recent aDNA studies on our view of third millennium Europe. European Journal of Archaeology 21: 159-191.

Furholt, M. (2019a). Re-integrating archaeology: A contribution to aDNA studies and the migration discourse on the 3rd millennium BC in Europe. Proceedings of the Prehistoric Society 85: 115-129.

Furholt, M. (2019b). De-contaminating the aDNA-Archaeology dialogue on mobility and migrationDiscussing the culture-historical legacy. Current Swedish Archaeology 27: 11-26.

Furholt, M., Grier, C., Spriggs, M., and Earle, T. (2020). Political economy in the archaeology of emergent complexity: A synthesis of bottom-up and top-down approaches. Journal of Archaeological Method and Theory 27: 157-191.

Furholt, M., and Müller, J. (2011). The earliest monuments in Europe - Architecture and social structures (5000-3000 BC). In Furholt, M., Lüth, F., and Müller, J. (eds.), Megaliths and Identities: Proceedings of the Third European Megalithic Studies Group Meeting in Kiel, 15th-19th of May 2010, Habelt, Bonn, pp. 15-32.

Gehlen, B. (2010). Innovationen und Netzwerke: Das Spätmesolithikum vom Forggensee (Südbayern) im Kontext des ausgehenden Mesolithikums und des Altneolithikums in der Südhälfte Europas Vol. 1-2, Welt und Erde, Loogh.

Gehlen, B., and Schön, W. (2003). Das "Spätmesolithikum” und das initiale Neolithikum in Griechenland - Implikationen für die Neolithisierung der alpinen und circumalpinen Gebiete. Archäologische Informationen 26: 255-273.

Gerling, C., Bánffy, E., Dani, J., Köhler, K., Kulcsár, G., Pike, A. W. G., Szeverényi, V., and Heyd, V. (2012). Immigration and transhumance in the Early Bronze Age Carpathian Basin: The occupants of a kurgan. Antiquity 86: 1097-1111.

Gimbutas, M. (1979). The three waves of Kurgan people into Old Europe, 4500-2500 BC. Archives Suisses d'Anthropologie Genérale 43: 113-137.

Gimbutas, M. (1991). The Civilization of the Goddess, Harper, San Francisco.

Goldberg, A., Günther, T., Rosenberg, N. A., and Jakobsson, M. (2017). Ancient X chromosomes reveal contrasting sex bias in Neolithic and Bronze Age Eurasian migrations. Proceedings of the National Academy of Sciences 114: 2657-2662.

Govedarica, B. (2004). Zepterträger - Herrscher der Steppen: Die frühen Ockergräber des älteren Äneolithikums im karpatenbalkanischen Gebiet und im Steppenraum Südost- und Osteuropas, von Zabern, Mainz am Rhein.

Graeber, D. (2014). Debt: The First 5000 Years-Updated and Expanded Edition, Melville House, Brooklyn.

Gramsch, A. (2011). Theory in central European archaeology: Dead or alive? In Bintliff, J. L., and Pearce, M. (eds.), The Death of Archaeological Theory, Oxbow Books, Oxford, pp. 48-71.

Greenfield, H. J. (2010). The secondary products revolution: The past, the present and the future. World Archaeology 42: 29-54.

Greiner, C. (2010). Patterns of translocality: Migration, livelihoods and identities in northwest Namibia. Sociologus 60: 131-161.

Greiner, C., and Sakdapolrak, P. (2013). Translocality: Concepts, applications and emerging research perspectives. Geography Compass 7: 373-384. 
Gronenborn, D. (1999). A variation on a basic theme: The transition to farming in southern central Europe. Journal of World Prehistory 13: 123-210.

Gronenborn, D. (2005). Klimaveränderungen und Kulturwandel in neolithischen Gesellschaften Mitteleuropas, 6700-2200 v. Chr., Römisch-Germanisches Zentralmuseum, Mainz.

Gronenborn, D. (2007). Beyond the models: Neolithisation in central Europe. In Whittle, A., and Cummings, V. (eds.), Going Over: The Mesolithic-Neolithic Transition in North-West Europe, Oxford University Press, Oxford, pp. 73-98.

Guilaine, J. (2018). A personal view of the Neolithisation of the western Mediterranean. Quaternary International 470: 211-225.

Haak, W., Forster, P., Bramanti, B., Matsumura, S., Brandt, G., Tänzer, M., et al. (2005). Ancient DNA from the first European farmers in 7500-year-old Neolithic sites. Science 310: 1016-1018.

Haak, W., Brandt, G., de Jong, H. N., Meyer, C., Ganslmeier, R., Heyd, V., Hawkesworth, C., Pike, A. W. G., Meller, H., and Alt, K. W. (2008). Ancient DNA, strontium isotopes, and osteological analyses shed light on social and kinship organization of the later Stone Age. Proceedings of the National Academy of Sciences 105: 18226-18231.

Haak, W., Balanovsky, O., Sanchez, J. J., Koshel, S., Zaporozhchenko, V., Adler, C. J., et al. (2010). Ancient DNA from European Early Neolithic farmers reveals their Near Eastern affinities. PLOS Biology 8: e1000536.

Haak, W., Lazaridis, I., Patterson, N., Rohland, N., Mallick, S., Llamas, B., et al. (2015). Massive migration from the steppe was a source for Indo-European languages in Europe. Nature 522: 207-211.

Hakenbeck, S. E. (2019). Genetics, archaeology and the far right: An unholy trinity. World Archaeology 51: $517-527$.

Hamblin, W. J. (2006). Warfare in the Ancient Near East to 1600 BC: Holy Warriors at the Dawn of History, Routledge, London.

Hansen, S. (2010). Communication and exchange between the northern Caucasus and central Europe in the fourth millennium BC. In Hansen, S., Hauptmann, A., Motzenbäcker, I., and Pernicka, E. (eds.), Von Majkop Bis Trialeti: Gewinnung Und Verbreitung von Metallen Und Obsidian in Kaukasien Im 4.-2. Jt. v. Chr., Habelt Verlag, Bonn, pp. 297-316.

Hansen, S. (2019). Noch einmal: Abschied von den Indogermanen. In Hansen, S., Molodin, V. I., and Mylnikova, L. M. (eds.), Mobilität und Migration: Konzepte, Methoden, Ergebnisse. Materialien Des 5. Internationalen Symposiums "Mobilität Und Migration: Konzepte, Methoden, Ergebnisse” (Denisova-Höhle (Altai, Russland), von 19. Bis 24. August 2019), Institute of Archaeology and Ethnography at the Siberian Branch of the Russian Academy of Sciences Publishing, Nowosibirsk, pp. 44-60.

Härke, H. (1995). "The Hun is a methodical chap": Reflections on the German tradition of pre- and protohistory. In Ucko, P. J. (ed.), Theory in Archaeology: A World Perspective, Routledge, London, pp. 46-90.

Hecht, D. (2007). Das schnurkeramische Siedlungswesen im südlichen Mitteileuropa: Eine Studie zu einer vernachlässigten Fundgattung im Übergang vom Neolithikum zur Bronzezeit, Ph.D. dissertation, Institut für Ur. und Frühgeschichte und Vorderasiastische Archäologie, Universität Heidelberg, Heidelberg.

Heyd, V. (2017). Kossinna's smile. Antiquity 91: 348-359.

Hinz, M., Feeser, I., Sjögren, K.-G., and Müller, J. (2012). Demography and the intensity of cultural activities: An evaluation of Funnel Beaker societies (4200-2800 cal BC). Journal of Archaeological Science 39: 3331-3340.

Hodder, I. (1982). Symbols in Action: Ethnoarchaeological Studies of Material Culture, Cambridge University Press, Cambridge.

Hodder, I. (2006). Çatalhöyük: The Leopard's Tale: Revealing the Mysteries of Turkey's Ancient "Town,” Thames and Hudson, London.

Hodder, I. (2014). Çatalhöyük: The leopard changes its spots: A summary of recent work. Anatolian Studies 64: 1-22.

Hodder, I., and Pels, P. (2010). "History houses": A new interpretation of architectural elaboration at Çatalhöyük. In Hodder, I. (ed.), Religion in the Emergence of Civilization: Çatalhöyük as a Case Study, Cambridge University Press, Cambridge, pp. 163-186.

Hofmann, D. (2015). What have genetics ever done for us? The implications of aDNA data for interpreting identity in Early Neolithic central Europe. European Journal of Archaeology 18: 454-476.

Hofmann, D. (2016). Keep on walking: The role of migration in Linearbandkeramik life. Documanta Praehistorica 43: 235-251. 
Hofmann, D. (2020). Not going anywhere? Migration as a social practice in the Early Neolithic Linearbandkeramik. Quaternary International, online first, $15^{\text {th }}$ April. https://doi.org/10.1016/j. quaint.2020.04.002

Hofmann, D., Ebersbach, R., Doppler, T., and Whittle, A. (2016). The life and times of the house: Multiscalar perspectives on settlement from the Neolithic of the northern alpine foreland. European Journal of Archaeology 19: 596-630.

Hofmanová, Z., Kreutzer, S., Hellenthal, G., Sell, C., Diekmann, Y., Díez-del-Molino, D., et al. (2016). Early farmers from across Europe directly descended from Neolithic Aegeans. Proceedings of the National Academy of Sciences 113: 6886-6891.

Horejs, B. (2016). Aspects of connectivity on the centre of the Anatolian Aegean coast in the 7 th millennium BC. In Molloy, B. (ed.), Of Odysseys and Oddities: Scales and Modes of Interaction between Aegean Societies and Their Neighbours: Sheffield Studies in Aegean Archaeology, Oxbow, Oxford, pp. 143-167.

Horejs, B., Milić, B., Ostmann, F., Thanheiser, U., Weninger, B., and Galik, A. (2015). The Aegean in the early 7th millennium BC: Maritime networks and colonization. Journal of World Prehistory 28: $289-330$.

Horn, C. (2018). Warfare vs. exchange? Thoughts on an integrative approach. In Horn, C., and Kristiansen, K. (eds.), Warfare in Bronze Age Society, Cambridge University Press, Cambridge, pp. 47-60.

Hübner, E. (2005). Jungneolithische Gräber auf der jütischen Halbinsel: Typologische und chronologische Studien zur Einzelgrabkultur, Det Kongelige Oldskriftselskab, Copenhagen.

Immel, A., Rinne, C., Meadows, J., Barquera, R., Szolek, A., Pierini, F. et al. (2019). Neolithic genomes reveal a distinct ancient HLA allele pool and population transformation in Europe. bioRxiv 851188 .

Immel, A., Țerna, S., Simalcsik, A., Susat, J., Šarov, O., Sîrbu, G., Hofmann, R., Müller, J., Nebel, A., and Krause-Kyora, B. (2020). Gene-flow from steppe individuals into Cucuteni-Trypillia associated populations indicates long-standing contacts and gradual admixture. Scientific Reports 10: $1-8$.

Ion, A. (2017). How interdisciplinary is interdisciplinarity? Revisiting the impact of a DNA research for the archaeology of human remains. Current Swedish Archaeology 25: 177-198.

Ivanova, M. (2013). The Black Sea and the Early Civilizations of Europe, the Near East and Asia, Cambridge University Press, Cambridge.

Iversen, R. (2015). The Transformation of Neolithic Societies: An Eastern Danish Perspective on the 3rd Millennium BC, Jutland Archaeological Society, Højbjerg.

Jakucs, J., Bánffy, E., Oross, K., Voicsek, V., Ramsey, C. B., Dunbar, E., et al. (2016). Between the Vinča and Linearbandkeramik worlds: The diversity of practices and identities in the 54th-53rd centuries cal BC in southwest Hungary and beyond. Journal of World Prehistory 29: 267-336.

Jakucs, J., Oross, K., Bánffy, E., Voicsek, V., Dunbar, E., Reimer, P., Bayliss, A., Marshall, P., and Whittle, A. (2018). Rows with the neighbours: The short lives of longhouses at the Neolithic site of Versend-Gilencsa. Antiquity 92: 91-117.

Jensen, J. (2001). Danmarks oldtid. Stenalder 13,000-2000f. Kr., Gyldendal, Copenhagen.

Jeunesse, Chr. (2010). Die Michelsberger Kultur: Jungsteinzeit im Umbruch: Die "Michelsberger Kultur" und Mitteleuropa vor 6000 Jahren, Badisches Landesmuseum Karlsruhe, Karlsruhe, pp. 46-55.

Johannsen, N. N. (2006). Draught cattle and the south Scandinavian economies of the 4th millennium BC. Environmental Archaeology 11: 35-48.

Johannsen, N. N., and Laursen, S. T. (2010). Routes and wheeled transport in late 4th-early 3rd millennium funerary customs of the Jutland Peninsula - Regional evidence and European context. Praehistorische Zeitschrift 85: 15-58.

Johannsen, N. N., Larson, G., Meltzer, D. J., and Linden, M. V. (2017). A composite window into human history. Science 356: 1118-1120.

Juras, A., Chyleński, M., Ehler, E., Malmström, H., Żurkiewicz, D., Włodarczak, P., et al. (2018). Mitochondrial genomes reveal an east to west cline of steppe ancestry in Corded Ware populations. Scientific Reports 8: 1-10.

Kaiser, E. (2019). Das dritte Jahrtausend im osteuropäischen Steppenraum: Kulturhistorische Studien zu prähistorischer Subsistenzwirtschaft und Interaktion mit Benachbarten Räumen, Berlin Studies of the Ancient World Vol. 37, Edition Topoi, Berlin. 
Kaiser, E., and Winger, K. (2015). Pit graves in Bulgaria and the Yamnaya culture. Praehistorische Zeitschrift 90: 114-140.

Kelly, R. C. (2000). Warless Societies and the Origin of War, University of Michigan Press, Ann Arbor.

Kind, C.-J. (1997). Die letzten Wildbeuter: Henauhof Nord II und das Endmesolithikum in Baden-Württemberg, Konrad Theiss, Stuttgart.

Kılınç, G. M., Omrak, A., Özer, F., Günther, T., Büyükkarakaya, A. M., Bıçakçı, E., et al. (2016). The demographic development of the first farmers in Anatolia. Current Biology 26: 2659-2666.

Klassen, L. (2004). Jade und Kupfer: Untersuchungen zum Neolithisierungsprozess im westlichen Ostseeraum unter besonderer Berücksichtigung der Kulturentwicklung Europas 5500-3500 BC, Aarhus University Press, Aarhus.

Kleijne, J. (2019). Embracing Bell Beaker: Adopting New Ideas and Objects Across Europe During the Later 3rd Millennium BC (c. 2600-2000 BC), Sidestone Press, Leiden.

Knipper, C., Mittnik, A., Massy, K., Kociumaka, C., Kucukkalipci, I., Maus, M., et al. (2017). Female exogamy and gene pool diversification at the transition from the Final Neolithic to the Early Bronze Age in central Europe. Proceedings of the National Academy of Sciences 114: 10083-10088.

Kohl, P. L. (2007). The Making of Bronze Age Eurasia, Cambridge University Press, Cambridge.

Korenevskij, S. (2010). Große Kurgane der Majkop-Kultur: Arbeitsaufwand und kultische Aspekte bei ihrer Errichtung. In Hansen, S., Hauptmann, A., Motzenbäcker, I., and Pernicka, E. (eds.), Von Maikop BisTrialeti. Gewinnung Und Verbreitung von Metallen Und Obsidian Im 4.-2. Jt. v. Chr., Dr. Rudolf Habelt GmbH, Bonn, pp. 59-73.

Kossinna, G. (1910). Der Ursprung der Urfinnen und Urindogermanen und ihre Ausbreitung nach Osten. Mannus I-II: $225-245$.

Kossinna, G. (1911). Die Herkunft der Germanen: Zur Methode der Siedlungsarchäologie, Kabitzsch, Leipzig.

Kossinna, G. (1919). Das Siegreiche Vordringen meiner wissenschaftlichen Anschauungen als Ergebnis meiner wissenschaftlichen Methode. Mannus 11/12: 396-404.

Kotsakis, K. (2006). Settlement of discord: Sesklo and the emerging household. In Tasic, N., and Grozdanov, C. (eds.), Homage to Milutin Garasanin, Serbian Academy of Sciences and Arts, Belgrade, pp. 207-220.

Krauß, R., Schmid, C., Kirschenheuter, D., Abele, J., Slavchev, V., and Weninger, B. (2017). Chronology and development of the Chalcolithic necropolis of Varna I. Documenta Praehistorica 44: 282-305.

Krause-Kyora, B., Makarewicz, C., Evin, A., Flink, L. G., Dobney, K., Larson, G., et al. (2013). Use of domesticated pigs by Mesolithic hunter-gatherers in northwestern Europe. Nature Communications 4: 2348 .

Kristiansen, K. (1989). Prehistoric migrations-The case of the single grave and Corded Ware culture. Journal of Danish Archaeology 8: 211-225.

Kristiansen, K. (2014). Towards a new paradigm? The third science revolution and its possible consequences in archaeology. Current Swedish Archaeology 22: 11-34.

Kristiansen, K., Allentoft, M. E., Frei, K. M., Iversen, R., Johannsen, N. N., Kroonen, G., et al. (2017). Re-theorising mobility and the formation of culture and language among the Corded Ware culture in Europe. Antiquity 91: 334-347.

Kroon, E. J., Huisman, D. J., Bourgeois, Q. P. J., Braekmans, D. J. G., and Fokkens, H. (2019). The introduction of Corded Ware culture at a local level: An exploratory study of cultural change during the Late Neolithic of the Dutch west coast through ceramic technology. Journal of Archaeological Science: Reports 26: 101873.

Kuijt, I. (2000). People and space in early agricultural villages: Exploring daily lives, community size and architecture in the late Pre-Pottery Neolithic A period mortuary practices. Journal of Anthropological Archaeology 19: 75-102.

Kunst, M. (2001). Invasion? Fashion? Social rank? Consideration concerning the Bell Beaker phenomenon in Copper Age fortifications of the Iberian Peninsula. In Nicolis, F. (ed.), Bell Beakers Today: Pottery, People, Culture, Symbols in Prehistoric Europe: Proceedings of the International Colloquium, Riva Del Garda (Trento, Italy), 11-16 May 1998, Ufficio Beni Archaeologici, Trento, pp. 81-90.

Kunst, M. (2007). Zambujal (Torres Vedras, Lisboa): Relatório das escavações de 2001. Revista Portuguesa de Arqueologia, 10,1,2007, Instituto Português de Arqueologia, Lisboa, pp. 95-118.

Laporte, L., Bizien-Jaglin, C., Blanchet, S., Brisotto, V., Ghesquière, E., Guyodo, J.-N., et al. (2016). D'une forme à l'autre: Diversité des architectures domestiques du Néolithique moyen dans l'ouest de la France. In Perrin, R., Chambon, P., Gibaja, J. F., and Goude, G. (eds.), Le Chasséen, des 
Chasséens...Retour sur une culture nationale et ses parallèles: Sepulcres de fossa, Cortaillod, Lagozza colloque international de Paris, 18-20 novembre 2014, Archives d'Écologie Préhistorique, Toulouse, pp. 331-351.

Lazaridis, I., Patterson, N., Mittnik, A., Renaud, G., Mallick, S., Kirsanow, K., et al. (2014). Ancient human genomes suggest three ancestral populations for present-day Europeans. Nature 513: $409-413$.

Lazaridis, I., Nadel, D., Rollefson, G., Merrett, D. C., Rohland, N., Mallick, S., et al. (2016). Genomic insights into the origin of farming in the ancient Near East. Nature 536: 419-424.

Lazaridis, I., and Reich, D. (2017). Failure to replicate a genetic signal for sex bias in the steppe migration into central Europe. Proceedings of the National Academy of Sciences 114: E3873-E3874.

Leppard, T. P. (2014). Mobility and migration in the Early Neolithic of the Mediterranean: Questions of motivation and mechanism. World Archaeology 46: 484-501.

Lerner, G. (1987). The Creation of Patriarchy, Oxford University Press, Oxford.

Leuzinger, U. (2002). Steinartefakte. In de Capitani, A., Deschler-Erb, A., Leuzinger, U., Marti-Grädel, E., and Schibler, J. (eds.), Die Jungsteinzeitliche Seeufersiedlung Arbon Bleiche 3. Funde, Archäologie im Thurgau, Frauenfeld, pp. 22-75.

López, S., van Dorp, L., and Hellenthal, G. (2016). Human dispersal out of Africa: A lasting debate. Evolutionary Bioinformatics Online 11: 57-68.

Luca, S. A., and Suciu, C. (2011). The First Neolithic Sites in Central/South-East European Transect Vol II: Early Neolithic (Starčevo-Cris) Sites on the Territory of Romania, BAR International Series No. 2188, Archaeopress, Oxford.

Lüning, J. (1972). Zum Kulturbegriff im Neolithikum. Praehistorische Zeitschrift 47: 145-173.

Lüning, J. (2000). Steinzeitliche Bauern in Deutschland: Die Landwirtschaft im Neolithikum, Habelt, Bonn.

Lüning, J. (2005). Bandkeramische Hofplätze und die absolute Chronologie der Bandkeramik. In Lüning, J., Frirdich, C., and Zimmermann, A. (eds.), Die Bandkeramik Im 21. Jahrhundert. Symposium in Der Abtei Brauweiler Bei Köln Vom 16.9.-19.9.2002, Verlag Marie Leidorf, Rahden, pp. 49-74.

Makarewicz, C. (2013). A pastoralist manifesto: Breaking stereotypes and re-conceptualizing pastoralism in the Near Eastern Neolithic. Levant 45: 159-174.

Manen, C., Perrin, T., Guilaine, J., Bouby, L., Bréhard, S., Briois, F., Durand, F., Marinval, P., and Vigne, J.-D. (2019). The Neolithic transition in the western Mediterranean: A complex and non-linear diffusion process - The radiocarbon record revisited. Radiocarbon 61: 531-571.

Maran, J. (2004). Kulturkontakte und Wege der Ausbreitung der Wagentechnologie im 4. Jahrtausend v. Chr. In Fansa, M., and Burmeister, S. (eds.), Rad Und Wagen: Der Ursprung Einer Innovation: Wagen Im Vorderen Orient Und Europa, von Zabern, Mainz, pp. 429-442.

Marciniak, A., Barański, M. Z., Bayliss, A., Czerniak, L., Goslar, T., Southon, J., and Taylor, R. E. (2015). Fragmenting times: Interpreting a Bayesian chronology for the Late Neolithic occupation of Çatalhöyük East, Turkey. Antiquity 89: 154-176.

Martínez, M. P. P., and Salanova, L. (2015). The Bell Beaker Transition in Europe: Mobility and Local Evolution During the 3rd Millennium BC, Oxbow Books, Oxford.

Mateiciucová, I. (2008). Talking Stones: The Chipped Stone Industry in Lower Austria and Moravia and the Beginnings of the Neolithic in Central Europe (LBK), 5700-4900 BC, Mazarykova Univerzita, Brno.

Mathieson, I., Lazaridis, I., Rohland, N., Mallick, S., Patterson, N., Roodenberg, S. A., et al. (2015). Genome-wide patterns of selection in 230 ancient Eurasians. Nature 528: 499-503.

Mathieson, I., Alpaslan-Roodenberg, S., Posth, C., Szécsényi-Nagy, A., Rohland, N., Mallick, S., et al. (2018). The genomic history of southeastern Europe. Nature 555: 197-203.

McMahon, A. (2019). Early urbanism in northern Mesopotamia. Journal of Archaeological Research 28: 289-337

Merpert, N. Y. (1974). Drevnejshie skotovody Volzhsko-Ural'skogo mezhdurech'ja, Academy, Moscow.

Meyer, C., Lohr, C., Gronenborn, D., and Alt, K. W. (2015). The massacre mass grave of Schöneck-Kilianstädten reveals new insights into collective violence in Early Neolithic central Europe. Proceedings of the National Academy of Sciences 112: 11217-11222.

Midgley, M. (1992). TRB Culture: The First Farmers on the North European Plain, Edinburgh University Press, Edinburgh.

Midgley, M. S. (2008). The Megaliths of Northern Europe, Routledge, London.

Müller, J. (1994). Das ostadriatische Frühneolithikum: Die Impresso-Kultur und die Neolithisierung des Adriaraumes, Spiess, Berlin. 
Müller, J. (1999). Radiokarbonchronologie - Keramikanalyse - Osteologie - Anthropologie - Raumanalysen: Beiträge zum Neolithikum und zur Frühbronzezeit im Mittelelbe-Saale-Gebiet. Bericht der Römisch-Germanischen Kommision 80: 25-212.

Müller, J. (2001). Soziochronologische Studien zum Jung- und Spätneolithikum im Mittelelbe-SaaleGebiet (4100-2700 v. Chr.), Verlag Marie Leidorf, Rahden.

Müller, J. (2002). Vom Endneolithikum zur Frühbronzezeit: Muster sozialen Wandels? (Tagung Bamberg 14.-16. Juni 2001), Habelt, Bonn.

Müller, J. (2011). Megaliths and Funnel Beakers: Societies in Change 4100-2700 BC, Stichting Nederlands Museum voor Anthropologie en Praehistorie, Amsterdam.

Müller, J. (2013). Kossinna, Childe and aDNA: Comments on the construction of identities. Current Swedish Archaeology 21: 35-37.

Myres, M. A. (1911). The Dawn of History, Williams and Norgate, London.

Oates, J., McMahon, A., Karsgaard, P., Quntar, S. A., and Ur, J. (2007). Early Mesopotamian urbanism: A new view from the north. Antiquity 81: 585-600.

Østmo, E. (1988). Etableringen av jordbrukskultur i Østfold i steinalderen, Universitetets Oldsaksamling, Oslo.

Olalde, I., Brace, S., Allentoft, M. E., Armit, I., Kristiansen, K., Booth, T., et al. (2018). The Beaker phenomenon and the genomic transformation of northwest Europe. Nature 555: 190-196.

Olalde, I., Mallick, S., Patterson, N., Rohland, N., Villalba-Mouco, V., Silva, M., et al. (2019). The genomic history of the Iberian Peninsula over the past 8000 years. Science 363: 1230-1234.

Omrak, A., Günther, T., Valdiosera, C., Svensson, E. M., Malmström, H., Kiesewetter, H., Aylward, W., Storå, J., Jakobsson, M., and Götherström, A. (2016). Genomic evidence establishes Anatolia as the source of the European Neolithic gene pool. Current Biology 26: 270-275.

Oross, K., Bánffy, E., Osztás, A., Marton, T., Nyerges, É. Á., Köhler, K., et al. (2016). The early days of Neolithic Alsónyék: The Starčevo occupation. Bericht der Römisch-Germanischen Kommission 94 : 93-121.

Orton, D. (2012). Herding, settlement, and chronology in the Balkan Neolithic. European Journal of Archaeology 15: 5-40.

Orton, D., Gaastra, J., and Linden, M. V. (2016). Between the Danube and the deep blue sea: Zooarchaeological meta-analysis reveals variability in the spread and development of Neolithic farming across the western Balkans. Open Quaternary 2: 6.

Osztás, A., Zalai-Gaál, I., Bánffy, E., Marton, T., Nyerges, É. Á., Köhler, K., et al. (2016). Coalescent community at Alsónyék: The timings and duration of Lengyel burials and settlement. Berichte der Römisch-Germanischen Kommission 94: 179-282.

Otte, M. (2009). The Paleolithic-Mesolithic transition. In Camps, M., and Chauhan, P. (eds.), Sourcebook of Paleolithic Transitions: Methods, Theories, and Interpretations, Springer, New York, pp. 537-553.

Özdoğan, M. (1998). An Early Neolithic Anatolian colony in the Balkans? In Anreiter, P., Bartosiewicz, L., Jerem, E., and Meid, W. (eds.), Man and the Animal World: Studies in Archaeozoology, Archaeology, Anthropology and Palaeolinguistics in Memoriam Sandor Bökönyi, Archaeolingua No. 8, Archaeolingua Alapítvány, Budapest, pp. 435-451.

Özdoğan, M. (2006). Neolithic cultures at the contact zone between Anatolia and the Balkans-Diversity and homogeneity at the Neolithic frontier. In Gatsov, I., and Schwarzberg, H. (eds.), Aegean - Marmara - Black Sea: The Present State of Research on the Early Neolithic: Proceedings of the Session Held at the EAA 8th Annual Meeting in Thessaloniki, 28th September 2002, Beier und Beran, Langenweissbach, pp. 21-28.

Özdoğan, M. (2011). An Anatolian perspective on the Neolithization process in the Balkans: New questions, new prospects. In Krauß, R. (ed.), Beginnings - New Research in the Appearance of the Neolithic between Northwest Anatolia and the Carpathian Basin, Marie Leidorf, Rahden, pp. 23-33.

Perlès, C. (2001). Early Neolithic in Greece: The First Farming Communities in Europe, Cambridge University Press, Cambridge.

Perrin, T., Manen, C., Valdeyron, N., and Guilaine, J. (2018). Beyond the sea... The Neolithic transition in the southwest of France. Quaternary International 470: 318-332.

Peter-Röcher, H. (2007). Gewalt und Krieg im prähistorischen Europa: Beiträge zur Konfliktforschung auf der Grundlage archäologischer, anthropologischer und ethnologischer Quellen., Habelt, Bonn.

Piezonka, H. (2008). The earliest pottery east of the Baltic Sea. In Proceedings of the International Workshop "Early Pottery in the Balti" in Schleswig, 20th-21st October 2006, Berichte der RömischGermanischen Kommission 89: 301-346. 
Pinhasi, R., Fort, J., and Ammerman, A. J. (2005). Tracing the origin and spread of agriculture in Europe. PLOS Biology 3: e410.

Prescott, C. (1996). Was there really a Neolithic in Norway? Antiquity 70: 77-87.

Prescott, C. (2013). Recurrent themes: Indo-Europeans in Norwegian archaeology. In Bergerbrant, S. and Sabatini, S. (eds.), Counterpoint: Essays in Archaeology and Heritage Studies in Honour of Professor Kristian Kristiansen, BAR International Series No. 2508, Archaeopress, Oxford, pp. 607-612.

Prescott, C., and Glørstad, H. (2015). Expanding 3rd millennium transformations: Norway. In Prieto Martínez, M. P., and Salanova, L. (eds.), The Bell Beaker Transition in Europe: Mobility and Local Evolution during the 3rd Millennium BC, Oxbow, Oxford, pp. 77-87.

Price, T. D., and Gebauer, A. B. (1992). The final frontier: Foragers to farmers in southern Scandinavia. In Price, T. D., and Gebauer, A. B. (eds.), Transitions to Agriculture in Prehistory, Prehistory Press, Madison, WI, pp. 97-115.

Prien, R. (2005). Archäologie und Migration: Vergleichende Studien zur archäologischen Nachweisbarkeit von Wanderungsbewegungen, Habelt, Bonn.

Ralph, S. (ed.) (2013). The Archaeology of Violence: Interdisciplinary Approaches, State University of New York Press, Albany.

Rascovan, N., Sjögren, K.-G., Kristiansen, K., Nielsen, R., Willerslev, E., Desnues, C., and Rasmussen, S. (2018). Emergence and spread of basal lineages of Yersinia pestis during the Neolithic decline. Cell 176: 295-305

Reingruber, A. (2008). Die Deutschen Ausgrabungen auf der Argissa-Magula II: Die Argissa-Magula: Das frühe und das beginnende mittlere Neolithikum im Lichte Transägäischer Beziehungen, Habelt, Bonn.

Reingruber, A. (2011). Early Neolithic settlement patterns and exchange networks in the Aegean. Documenta Praehistorica XXXVIII Neolithic Studies 18: 291-306.

Richard, H. (2004). Néolithisation précoce: Premières traces d'anthropisation du couvert végétal à partir des données polliniques, Presses Universitaires de Franche-Comté, Besançon.

Robb, J. (2007). The Early Mediterranean Village: Agency, Material Culture, and Social Change in Neolithic Italy, Cambridge University Press, Cambridge.

Robb, J. (2013). Material culture, landscapes of action, and emergent causation: A new model for the origins of the European Neolithic. Current Anthropology 54: 657-683.

Robb, J. E., and Miracle, P. (2007). Beyond "migration" versus "acculturation": New models for the spread of agriculture. In Whittle, A., and Cummings, V. (eds.), Going Over: The Mesolithic-Neolithic Transition in North-Western Europe, Oxford University Press, Oxford, pp. 99-115.

Robb, J., and Harris, O. J. T. (2018). Becoming gendered in European prehistory: Was Neolithic gender fundamentally different? American Antiquity 83: 128-147.

Roberts, B. W., and Vander Linden, M. (eds.) (2011). Investigating Archaeological Cultures, Springer, New York.

Rosenstock, E. (2009). Tells in Südwestasien und Südosteuropa, Greiner, Remshalden.

Salzman, E. (2010). Poselenija kultury schnurowoi keramiku na territorii Kalinigradskoi oblasti, Russian Academy of Sciences, Archaeological Institute Moscow, Moscow.

Sánchez-Quinto, F., Malmström, H., Fraser, M., Girdland-Flink, L., Svensson, E. M., Simões, L. G., et al. (2019). Megalithic tombs in western and northern Neolithic Europe were linked to a kindred society. Proceedings of the National Academy of Sciences 116: 9469-9474.

Scarre, C. (2011). Landscapes of Neolithic Brittany, Oxford University Press, Oxford.

Schachner, G. (2012). Population Circulation and the Transformation of Ancient Zuni Communities, University of Arizona Press, Tucson.

Schoop, U.-D. (2005). The late escape of the Neolithic from the central Anatolian plain. In Lichter, C. (ed.), How Did Farming Reach Europe? Deutsches Archäologisches Institut, Istanbul, pp. 41-58.

Schroeder, H., Margaryan, A., Szmyt, M., Theulot, B., Włodarczak, P., Rasmussen, S., et al. (2019). Unraveling ancestry, kinship, and violence in a Late Neolithic mass grave. Proceedings of the National Academy of Sciences 116: 10705-10710.

Schubert, H. (1999). Die bemalte Keramik des Frühneolithikums in Südosteuropa, Italien und Westanatolien, Marie Leidorf, Rahden.

Schulting, R. (2013). War without warriors? The nature of interpersonal conflict before the emergence of formalized warrior elites. In Ralph, S. (ed.), The Archaeology of Violence: Interdisciplinary Approaches, State University of New York Press, Albany, pp. 19-36.

Schultrich, S. (2019). Das Jungneolithikum in Schleswig-Holstein, Sidestone Press, Leiden. 
Shennan, S. (1976). Bell Beakers and their context in central Europe. In Lanting, J. N., and van der Waals, J. D. (eds.), Glockenbechersymposium Oberried 1974, Fibula-Van Dishoeck, Oberried, pp. 231-240.

Shennan, S. (1989). Introduction: Archaeological approaches to cultural identity. In Shennan, S. (ed.), Archaeological Approaches to Cultural Identity, Unwin Hyman, London, pp. 1-32.

Shennan, S. (2009). Evolutionary demography and the population history of the European Early Neolithic. hbio 81: 339-355.

Shennan, S. (2018). The First Farmers of Europe: An Evolutionary Perspective, Cambridge University Press, Cambridge.

Shennan, S. J., Crema, E. R., and Kerig, T. (2015). Isolation-by-distance, homophily, and "core" vs. "package" cultural evolution models in Neolithic Europe. Evolution and Human Behavior 36: 103-109.

Sherratt, A. (1981). Plough and pastoralism: Aspects of the secondary products revolution. In Hodder, I., Isaac, G., and Hammond, N. (eds.), Pattern of the Past: Studies in Honour of David Clarke, Cambridge University Press, Cambridge, pp. 261-305.

Sherratt, A. (1990). The genesis of megaliths: Monumentality, ethnicity and social complexity in Neolithic north-west Europe. World Archaeology 22: 147-167.

Silk, J. B. (1980). Adoption and kinship in Oceania. American Anthropologist 82: 799-820.

Sjögren, K.-G., Price, T. D., and Kristiansen, K. (2016). Diet and mobility in the Corded Ware of central Europe. PLOS ONE 11: e0155083.

Skoglund, P., Malmström, H., Omrak, A., Raghavan, M., Valdiosera, C., Günther, T., et al. (2014). Genomic diversity and admixture differs for stone-age Scandinavian foragers and farmers. Science 344: 747-750.

Skourtanioti, E., Erdal, Y. S., Frangipane, M., Restelli, F. B., Yener, K. A., Pinnock, F., et al. (2020). Genomic history of Neolithic to Bronze Age Anatolia, northern Levant, and southern Caucasus. Cell 181: 1158-1175.e28.

Sørensen, L. (2014). From Hunter to Farmer in Northern Europe: Migration and Adaptation during the Neolithic and Bronze Age, Wiley Blackwell, Copenhagen.

Sørensen, T. F. (2017). The two cultures and a world apart: Archaeology and science at a new crossroads. Norwegian Archaeological Review 50: 101-115.

Stäuble, H. (1995). Radiocarbon dates of the earliest Neolithic in central Europe. Radiocarbon 37: 227-237.

Stein, G. J. (2012). The development of indigenous social complexity in Late Chalcolithic Upper Mesopotamia in the 5th-4th millennia BC - An initial assessment. Origini 24: 115-142.

Strahm, C. (2002). Tradition und Wandel der sozialen Strukturen vom 3. zum 2. vorchristlichen Jahrtausend. In Müller, J. (ed.), Vom Endneolithikum Zur Frühbronzezeit: Muster Sozialen Wandels? (Tagung Bamberg 14.-16. Juni 2001), Habelt, Bonn, pp. 175-194.

Suter, P. (2017). Um 2700 v. Chr. Wandel und Kontinuität in den Ufersiedlungen am Bielersee, Archäologischer Dienst des Kantons Bern, Bern.

Szécsényi-Nagy, A., Brandt, G., Haak, W., Keerl, V., Jakucs, J., Möller-Rieker, S., et al. (2015). Tracing the genetic origin of Europe's first farmers reveals insights into their social organization. Proceedings of the Royal Society of London B: Biological Sciences 282: 20150339.

Szécsényi-Nagy, A., Roth, C., Brandt, G., Rihuete-Herrada, C., Tejedor-Rodríguez, C., Held, P., et al. (2017). The maternal genetic make-up of the Iberian Peninsula between the Neolithic and the Early Bronze Age. Scientific Reports 7: 15644.

Szmyt, M. (1999). Between West and East: People of the Globular Amphora Culture in Eastern Europe: 2950-2350 BC, Adam Mickiewicz University, Poznań.

Tarrús, J. (2008). La Draga (Banyoles, Catalonia), an Early Neolithic lakeside village in Mediterranean Europe. Catalan Historical Review 1: 17-33.

Tasić, N., Marić, M., Filipović, D., Penezić, K., Dunbar, E., Reimer, P., Barclay, A., Bayliss, A., Gaydarska, B., and Whittle, A. (2016). Interwoven strands for refining the chronology of the Neolithic tell of Vinča-Belo Brdo, Serbia. Radiocarbon 58: 795-831.

Terrell, J., and Modell, J. (1994). Anthropology and adoption. American Anthropologist 96: 155-161.

Teschler-Nicola, M. (2012). The Early Neolithic site Asparn/Schletz (Lower Austria): Anthropological evidence of interpersonal violence. In Schulting, R. J., and Fibiger, L. (eds.), Sticks, Stones, and Broken Bones: Neolithic Violence in a European Perspective, Oxford University Press, Oxford, pp. 101-120. 
Thomas, J. (1988). Neolithic explanations revisited: The Mesolithic-Neolithic transition in Britain and south Scandinavia. Proceedings of the Prehistoric Society 54: 59-66.

Thomas, J. (1999). Understanding the Neolithic, 2nd ed., Routledge, London.

Thorpe, I. J. N. (2003). Anthropology, archaeology, and the origin of warfare. World Archaeology 35: $145-165$.

Tillmann, A. (1993). Kontinuität oder Diskontinuität? Zur Frage einer bandkeramischen Landnahme im südlichen Mitteleuropa. Archäologische Informationen 16: 157-187.

Timpson, A., Colledge, S., Crema, E., Edinborough, K., Kerig, T., Manning, K., Thomas, M. G., and Shennan, S. (2014). Reconstructing regional population fluctuations in the European Neolithic using radiocarbon dates: A new case-study using an improved method. Journal of Archaeological Science 52: 549-557.

Trifonov, V. (2004). Die Majkop-Kultur und die ersten Wagen in der südrussischen Steppe. In Fansa, M., and Burmeister, S. (eds.), Rad Und Wagen: Der Ursprung Einer Innovation: Wagen Im Vorderen Orient Und Europa, Philipp von Zabern, Mainz, pp. 167-176.

Trigger, B. (2006). A History of Archaeological Thought, 2nd ed., Cambridge University Press, Cambridge.

Tringham, R. (2014). Hunters, Fishers and Farmers of Eastern Europe, 6000-3000 BC, Routledge, London.

Ur, J. A., Karsgaard, P., and Oates, J. (2007). Early urban development in the Near East. Science 317: 1188.

Valdiosera, C., Günther, T., Vera-Rodríguez, J. C., Ureña, I., Iriarte, E., Rodríguez-Varela, R., et al. (2018). Four millennia of Iberian biomolecular prehistory illustrate the impact of prehistoric migrations at the far end of Eurasia. Proceedings of the National Academy of Sciences 115: 3428-3433.

Valera, A. C., and Criado Boado, F. (2018). Genética de una "fake news": Respuesta a las noticias sobre "invasiones" y "exterminios" en el III milenio antes de nuestra era en la Península Ibérica. Las gafas de Childe. https://lasgafasdechilde.es/genetica-de-una-fake-news-respuesta-a-las-noticiassobre-invasiones-y-exterminios-en-el-iii-milenio-antes-de-nuestra-era-en-la-peninsula-iberica/

van Willigen, S. (2006). Die Neolithisierung im nordwestlichen Mittelmeerraum, Philipp von Zabern, Mainz am Rhein.

Vander Linden, M. (2006). Le phénomène campaniforme dans l'Europe du 3ème millénaire avant notre ère: Synthèse et nouvelles perspectives, BAR International Series No. 1470, Archaeopress, Oxford.

Vander Linden, M. (2007). What linked the bell beakers in the third millennium Europe? Antiquity 81: 343-352.

Vander Linden, M. (2015). Bell Beaker pottery and society. In Fowler, C., Harding, J., and Hofmann, D. (eds.), The Oxford Handbook of Neolithic Europe, Oxford University Press, Oxford, pp. 605-620.

Vander Linden, M. (2016). Population history in third-millennium-BC Europe: Assessing the contribution of genetics. World Archaeology 48: 714-728.

Veit, U. (1989). Ethnic concepts in German prehistory: A case study on the relationship between cultural identity and archaeological objectivity. In Shennan, A. (ed.), Archaeological Approaches to Cultural Identity, Unwin Hyman, London, pp. 35-55.

Wahl, J., and Trautmann, I. (2012). Neolithic massacre at Talheim: A pivotal find in conflict archaeology. In Schulting, R. J., and Fibiger, L. (eds.), Sticks, Stones, and Broken Bones: Neolithic Violence in a European Perspective, Oxford University Press, Oxford, pp. 77-100.

Wang, C.-C., Reinhold, S., Kalmykov, A., Wissgott, A., Brandt, G., Jeong, C., et al. (2019). Ancient human genome-wide data from a 3000-year interval in the Caucasus corresponds with eco-geographic regions. Nature Communications 10: 590.

Weninger, B., Clare, L., Gerritsen, F. A., Horejs, B., Krauß, R., Linstädter, J., Özbal, R., and Rohling, E. J. (2014). Neolithisation of the Aegean and southeast Europe during the 6600-6000 calBC period of rapid climate change. Dokumenta Praehistorica 41: 1-31.

Whittle, A. (1996). Europe in the Neolithic: The Creation of New Worlds, Cambridge University Press, Cambridge.

Whittle, A. (2007). The Early Neolithic on the Great Hungarian Plain: Investigations of the Körös Culture Site of Ecsegfalva 23, County Békés, Archaeological Institute of the HAS, Budapest.

Whittle, A. (2010). The Körös culture of the Great Hungarian Plain: Implications of a recent research project at Ecsegfalva, Co. Békés. In Petrasch, D., and Gronenborn, J. (eds.), Die Neolithisierung Mitteleuropas: Internationale Tagung, Mainz 24. bis 26. Juni 2005, Verlag des Römisch-Germanischen Zentralmuseums, Mainz, pp. 189-210. 
Whittle, A. (2018). The Times of their Lives: Hunting History in the Archaeology of Neolithic Europe, Oxbow Books, Oxford.

Whittle, A., Healy, F., and Bayliss, A. (2011). Gathering Time: Dating the Early Neolithic Enclosures of Southern Britain and Ireland, Oxbow, Oxford.

Willcox, G. (2012). The beginnings of cereal cultivation and domestication in southwest Asia. In Potts, D. T. (ed.), A Companion to the Archaeology of the Ancient Near East, Blackwell, Oxford, pp. $163-180$.

Woidich, M. (2014). Die Westliche Kugelamphorenkultur: Untersuchungen zu ihrer raumzeitlichen Differenzierung, kulturellen und anthropologischen Identität, De Gruyter, Berlin.

Woodburn, J. (1982). Egalitarian societies. Man 17: 431-451.

Wotzka, H.-P. (1993). Zum traditionellen Kulturbegriff in der prähistorischen Archäologie. Paideuma 39: $25-44$.

Zalai-Gaál, I., Gál, E., Köhler, K., Osztás, A., and Szilágyi, K. (2012). Präliminarien zur Sozialarchäologie des lengyelzeitlichen Gräberfeldes von Alsónyék-Bátaszék, Südtransdanubien. Praehistorische Zeitschrift 87: 58-82.

Zeng, T. C., Aw, A. J., and Feldman, M. W. (2018). Cultural hitchhiking and competition between patrilineal kin groups explain the post-Neolithic Y-chromosome bottleneck. Nature Communications 9: 2077.

Zilhão, J. (2000). From the Mesolithic to the Neolithic in the Iberian Peninsula. In Price, T. D. (ed.), Europe's First Farmers, Cambridge University Press, New York, pp. 144-182.

Zilhão, J. (2001). Radiocarbon evidence for maritime pioneer colonization at the origins of farming in west Mediterranean Europe. Proceedings of the National Academy of Sciences 98: $14180-14185$.

Zimmermann, A., Meurers-Balke, J., and Kalis, A. (2005). Das Neolithikum im Rheinland. Die Ausbreitung des Neolithikums und das Verhältnis der frühen Bauern zu den spätmesolithischen Sammlerinnen und Jägern. Bonner Jahrbuch 205: 159-202.

Zvelebil, M. (1994). Neolithisation in eastern Europe. Poročilo o Raziskovanju 22: 107-151.

Zvelebil, M. and Pettitt, P. (2012). Biosocial archaeology of the Early Neolithic: Synthetic analyses of a human skeletal population from the LBK cemetery of Vedrovice, Czech Republic. Journal of Anthropological Archaeology 32: 313-329

Zvelebil, M., and Rowley-Conwy, P. (1984). Transition to farming in northern Europe: A hunter-gatherer perspective. Norwegian Archaeological Review 17: 104-128.

\section{Bibliography of Recent Literature}

Bickle, P. (2019). Thinking gender differently: New approaches to identity difference in the central European Neolithic. Cambridge Archaeological Journal 30: 201-218.

Cramp, L. J. E., Ethier, J., Urem-Kotsou, D., Bonsall, C., Borić, D., Boroneanţ, A., et al. (2019). Regional diversity in subsistence among early farmers in southeast Europe revealed by archaeological organic residues. Proceedings of the Royal Society B: Biological Sciences 286: 20182347.

Demoule, J.-P. (2007). La révolution néolithique en France, La Découverte, Paris.

Douka, K., Efstratiou, N., Hald, M. M., Henriksen, P. S., and Karetsou, A. (2017). Dating Knossos and the arrival of the earliest Neolithic in the southern Aegean. Antiquity 91: 304-321.

Efstratiou, N. ed. (2013). The Neolithic Settlement of Knossos in Crete: New Evidence for the Early Occupation of Crete and the Aegean Islands, INSTAP Academic Press, Philadelphia.

Frantz, L. A. F., Haile, J., Lin, A. T., Scheu, A., Geörg, C., Benecke, N., et al. (2019). Ancient pigs reveal a near-complete genomic turnover following their introduction to Europe. Proceedings of the National Academy of Sciences 116: 17231-17238.

Furholt, M., Müller-Scheeßel, N., Wunderlich, M., Cheben, I., and Müller, J. (2020). Communality and discord in an Early Neolithic settlement agglomeration: The LBK site of Vráble, southwest Slovakia. Cambridge Archaeological Journal 30: 469-489

Gallego-Llorente, M., Connell, S., Jones, E. R., Merrett, D. C., Jeon, Y., Eriksson, A., et al. (2016). The genetics of an Early Neolithic pastoralist from the Zagros, Iran. Scientific Reports 6: 1-7. 
Gillis, R. E., Kovačiková, L., Bréhard, S., Guthmann, E., Vostrovská, I., Nohálová, H., et al. (2017). The evolution of dual meat and milk cattle husbandry in Linearbandkeramik societies. Proceedings of the Royal Society B: Biological Sciences. 284: 20170905.

Hachem, L., and Hamon, C. (2014). Linear pottery culture household organisation. An economic model. In Whittle, A., and Bickle, P. (eds.), Early Farmers: The View from Archaeology and Science, Oxford University Press, Oxford, pp. 159-180.

Hervella, M., Rotea, M., Izagirre, N., Constantinescu, M., Alonso, S., Ioana, M., et al. (2015). Ancient DNA from south-east Europe reveals different events during Early and Middle Neolithic influencing the European genetic heritage. PLOS ONE 10: e0128810.

Hofmann, R., Medović, A., Furholt, M., Medović, I., Stankovic-Pesterac, T., Dreibrodt, S., Martini, S., and Hofmann, A. (2019). Late Neolithic multicomponent sites of the Tisa region and the emergence of centripetal settlement layouts. Praehistorische Zeitschrift 94: 351-378.

Hofmann, R., Müller, J., Shatilo, L., Videiko, M., Ohlrau, R., Rud, V., Burdo, N., Corso, M. D., Dreibrodt, S., and Kirleis, W. (2019). Governing Tripolye: Integrative architecture in Tripolye settlements. PLOS ONE 14: e0222243.

Jay, F., Boitard, S., and Austerlitz, F. (2019). An ABC method for whole-genome sequence data: Inferring Paleolithic and Neolithic human expansions. Molecular Biology and Evolution 36: 1565-1579.

Klassen, L. (ed.) (2020). The Pitted Ware Culture on Djursland: Supra-regional Significance and Contacts in the Middle Neolithic of Southern Scandinavia, Aarhus University Press, Aarhus.

Kleijne, J., Furholt, M., and Müller, J. (eds.) (2018). Think Global, Act Local! Bell Beakers in Europe: Proceedings of the Bell Beaker Workshop Kiel 2017, Journal of Neolithic Archaeology Special Issue 4, Habelt, Bonn.

Klejn, L. S., Haak, W., Lazaridis, I., Patterson, N., Reich, D., Kristiansen, K., Sjögren, K.-G., Allentoft, M., Sikora, M., and Willerslev, E. (2018). Discussion: Are the origins of Indo-European languages explained by the migration of the Yamnaya culture to the west? European Journal of Archaeology 21: 3-17.

Krause-Kyora, B., Susat, J., Key, F. M., Kühnert, D., Bosse, E., Immel, A., et al. (2018). Neolithic and medieval virus genomes reveal complex evolution of hepatitis B. eLife 7: e36666.

Kuhn, J. M. M., Jakobsson, M., and Günther, T. (2018). Estimating genetic kin relationships in prehistoric populations. PLOS ONE 13: e0195491.

Le Roy, M., Rivollat, M., Mendisco, F., Pemonge, M.-H., Coutelier, C., Couture, C., Tillier, A., Rottier, S., and Deguilloux, M.-F. (2016). Distinct ancestries for similar funerary practices? A GIS analysis comparing funerary, osteological and aDNA data from the Middle Neolithic necropolis Gurgy "Les Noisats" (Yonne, France). Journal of Archaeological Science 73: 45-54.

Makarewicz, C. A. (2020). The adoption of cattle pastoralism in the Arabian Peninsula: A reappraisal. Arabian Archaeology and Epigraphy 31: 168-177.

Makarewicz, C. A., and Pleuger, S. (2020). Herder-hunter- fishers and agricultural contacts: Zooarchaeological perspectives on Pitted Ware animal exploitation strategies on Djursland. In Klassen, L. (ed.), The Pitted Ware Culture on Djursland: Supra-regional Significance and Contacts in the Middle Neolithic of Southern Scandinavia, Aarhus University Press, Aarhus, pp. 277-337.

Malmström, H., Günther, T., Svensson, E. M., Juras, A., Fraser, M., Munters, A. R., et al. (2019). The genomic ancestry of the Scandinavian Battle Axe culture people and their relation to the broader Corded Ware horizon. Proceedings of the Royal Society B: Biological Sciences 286: 20191528.

Marcus, J. H., Posth, C., Ringbauer, H., Lai, L., Skeates, R., Sidore, C., et al. (2017). Archaeoecology of Neolithisation: Human-environment interactions in the NE Iberian Peninsula during the Early Neolithic. Journal of Archaeological Science: Reports 15: 437-445.

Narasimhan, V. M., Patterson, N., Moorjani, P., Rohland, N., Bernardos, R., Mallick, S., et al. (2019). The formation of human populations in south and central Asia. Science 365: eaat7487.

Palumbi, G. (2012). The Arslantepe royal tomb and the "manipulation" of the Kurgan ideology in eastern Anatolia at the beginning of the third millennium. MOM Éditions 58: 47-59.

Parkinson, W. A., Gyucha, A., Karkanas, P., Papadopoulos, N., Tsartsidou, G., Sarris, A., Duffy, P. R., and Yerkes, R. W. (2018). A landscape of tells: Geophysics and microstratigraphy at two Neolithic tell sites on the Great Hungarian Plain. Journal of Archaeological Science: Reports 19: 903-924.

Parkinson, W. A., Yerkes, R. W., Gyucha, A., Sarris, A., Morris, M., and Salisbury, R. B. (2010). Early Copper Age settlements in the Körös region of the Great Hungarian Plain. Journal of Field Archaeology 35: 164-183. 
Perlès, C., Quiles, A., and Valladas, H. (2013). Early seventh-millennium AMS dates from domestic seeds in the Initial Neolithic at Franchthi Cave (Argolid, Greece). Antiquity 87: 1001-1015.

Reingruber, A., and Thissen, L. (2005). 14C database for the Aegean catchment (eastern Greece, southern Balkans and western Turkey). In Lichter, C. (ed.), How Did Farming Reach Europe? Ege Yayınları, Istanbul, pp. 295-327.

Rivollat, M., Mendisco, F., Pemonge, M.-H., Safi, A., Saint-Marc, D., Brémond, A., Couture-Veschambre, C., Rottier, S., and Deguilloux, M.-F. (2015). When the waves of European Neolithization met: First paleogenetic evidence from early farmers in the southern Paris Basin. PLOS ONE 10: e0125521.

Robson, H. K., Skipitytė, R., Piličiauskienė, G., Lucquin, A., Heron, C., Craig, O. E., and Piličiauskas, G. (2019). Diet, cuisine and consumption practices of the first farmers in the southeastern Baltic. Archaeological and Anthropological Sciences 11: 4011-4024.

Salanova, L. (2016). Behind the warriors: Bell Beakers and identities in Atlantic Europe (third millennium BC). In Koch, J. T., and Cunliffe, B. (eds.), Celtic from the West 3: Atlantic Europe in the Metal Ages-Questions of Shared Language, Oxbow Books, Oxford, pp. 13-34.

Scheu, A., Powell, A., Bollongino, R., Vigne, J.-D., Tresset, A., Çakırlar, C., Benecke, N., and Burger, J. (2015). The genetic prehistory of domesticated cattle from their origin to the spread across Europe. BMC Genetics 16: 54.

Tassi, F., Vai, S., Ghirotto, S., Lari, M., Modi, A., Pilli, E., et al. (2017). Genome diversity in the Neolithic Globular Amphorae culture and the spread of Indo-European languages. Proceedings of the Royal Society B: Biological Sciences 284: 20171540.

Ventresca Miller, A. R., and Makarewicz, C. A. (2019). Intensification in pastoralist cereal use coincides with the expansion of trans-regional networks in the Eurasian steppe. Scientific Reports 9: 8363.

Whittle, A., Bayliss, A., Barclay, A., Gaydasrka, B., Bánffy, E., Borić, D., et al. (2016). A Vinča potscape: Formal chronological models for the use and development of Vinča ceramics in south-east Europe. Documenta Praehistorica XLII 43: 1-60.

Publisher's Note Springer Nature remains neutral with regard to jurisdictional claims in published maps and institutional affiliations. 